Historic, Archive Document

Do not assume content reflects current scientific knowledge, policies, or practices. 

Catalogue Number Thirty-One

SPRING AND FALL 1914
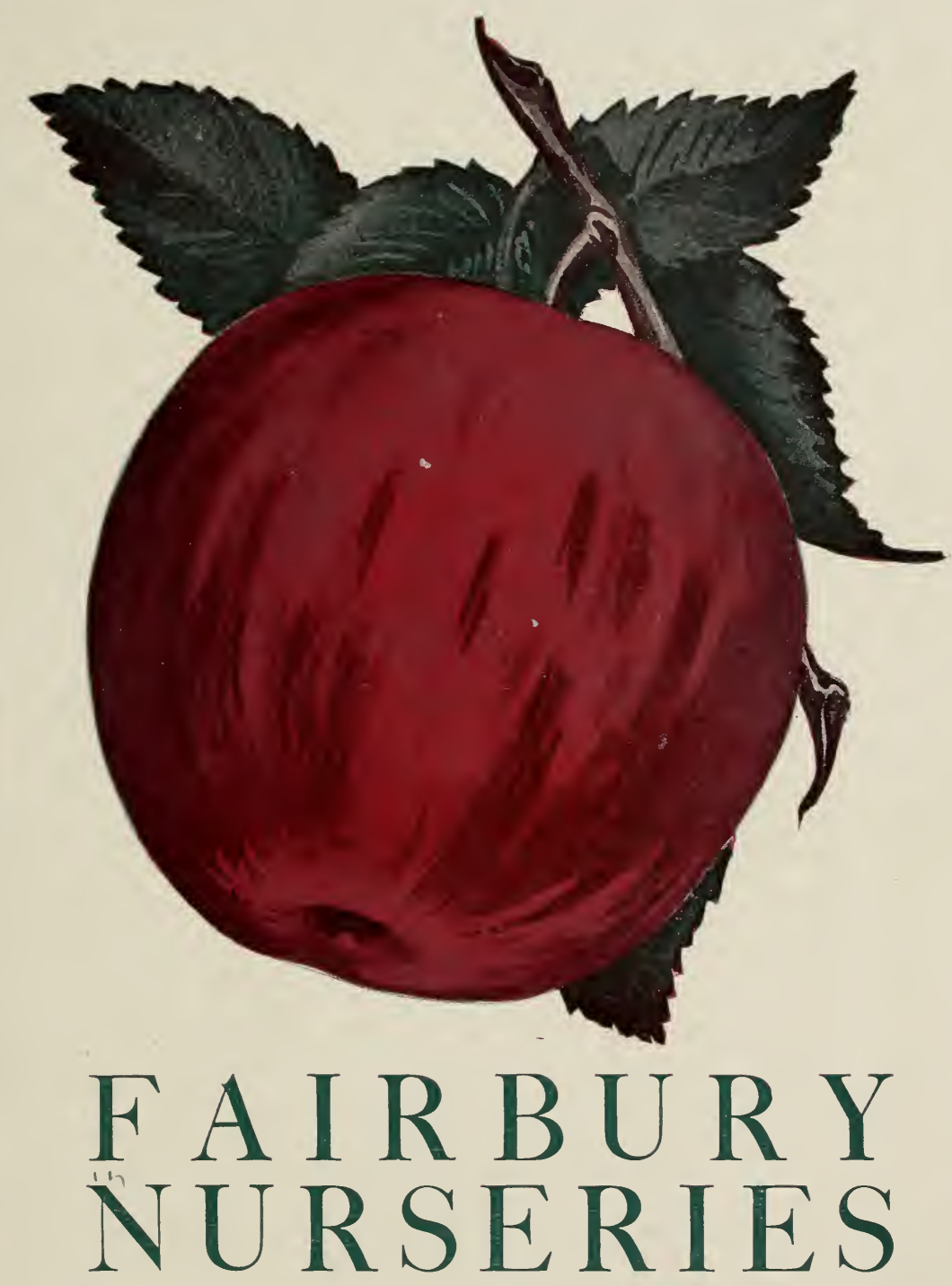

C. M. Hurlburt, Mgr. FAIRBURY, NEBR. 


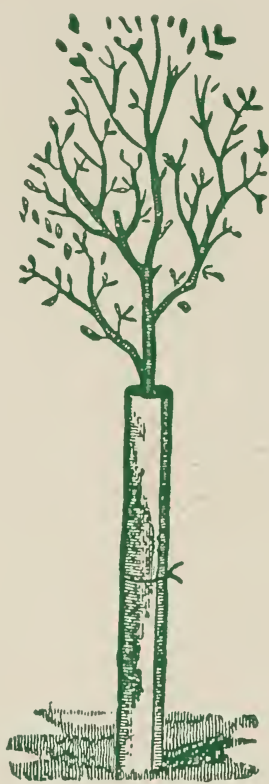

\section{TREE PROTECTORS}

\section{Price-2 Cents Each; $\$ 1.50$ per 100}

Same are made of veneer and are the best and easiest applied of anything ever used. Two men can wrap 1,000 trees a day. They are 18 to 24 inches long, 9 to 12 inches wide and one-twelfth inch thick, and are fastened with small wire around the center, and will last from three to five years.

Will protect your trees from rabbits, mice and borers; will also protect the stems from sunscald, and can be left on during the summer and will not injure the tree. They are furnished green, tied in bundles of 100 each, and are ready for use:

\section{PLANTS}

In the spring of each year we grow iarge quantities of such plants as Sweet Potatoes, Tomatoes, Cabbage, Peppers and Celery." We ship by prepaid postage, or where sent by express the customer pays the expressage.

\section{SWEET POTATOES}

Yellow Nansemon and Yellow Jersey

Plants are usually ready for shipment May 10.

$$
\text { Per }
$$

Per

By Mail, prepaid

$\$ 0.50$

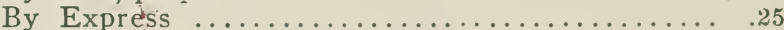

\section{TOMATOES}

\section{Earlyanna, Champion and Stone}

By Mail ............................ \$0.75

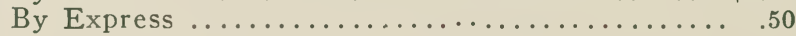

\section{CABBAGE}

Early Wakefield, Surehead and Holland Seed

By Mail .......................... \$0.50

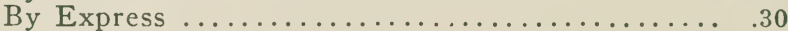

By Express, Surehead after June $1 \ldots \ldots \ldots \ldots . .25$

\section{GELERY}

Golden Self Blanching and Silver Plume June 1.

Celery grows very slowly when small and we cannot ship until

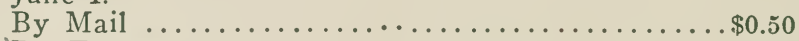

By Express ...................................

\section{PEPPER}

Giant Sweet, Mango and Cayenne

By Mail .......................... \$1.00

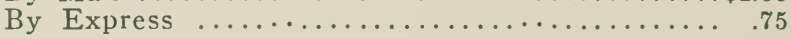

\section{EGG PLANT}

10 cents per dozen 


\title{
FAIRBURY NURSERIES
}

\author{
C. M. HURLBURT. Mgr.
}

Pairbury. Nebraska

All remittances by Postoffice Order, Express Money Order, Bank Draft and Registered Letter at niy risk. Do not send money in ordinary letters without registering it-it is not safe.

\section{ALL POSTOFFICE MONEY ORDERS must be made out on Fairbury, Nebraska}

Your Name.

Postoffice.

County.

State

Name Your Freight Station.

How to be Sent, Freight, Express, Mail

Name Your Railroad Co.
Amt. Enc. P. O. Order, \$

Amt. Enc. Exp. ..... \$

Amt. Enc. Draft ......\$

Amt. Enc. Cash .....\$

Amt. Enc. Stamps ....\$

Total $\ldots \ldots \ldots \ldots$.......

Date

191

Very Important-No difference how often you have written us, always give your Full Address and write your Name, Postoffice, County and State very plainly; by so doing you will save much trouble and avoid the possibility of delay and mistake in filling your orders.

\begin{tabular}{l||c||c||c|c|c|}
\hline Number & NAME AND SIZE OF ARTICLE & \multicolumn{2}{|c|}{ Price } \\
\hline Dollars Cents \\
\hline
\end{tabular}




\section{ORDER SHEET-Continued}

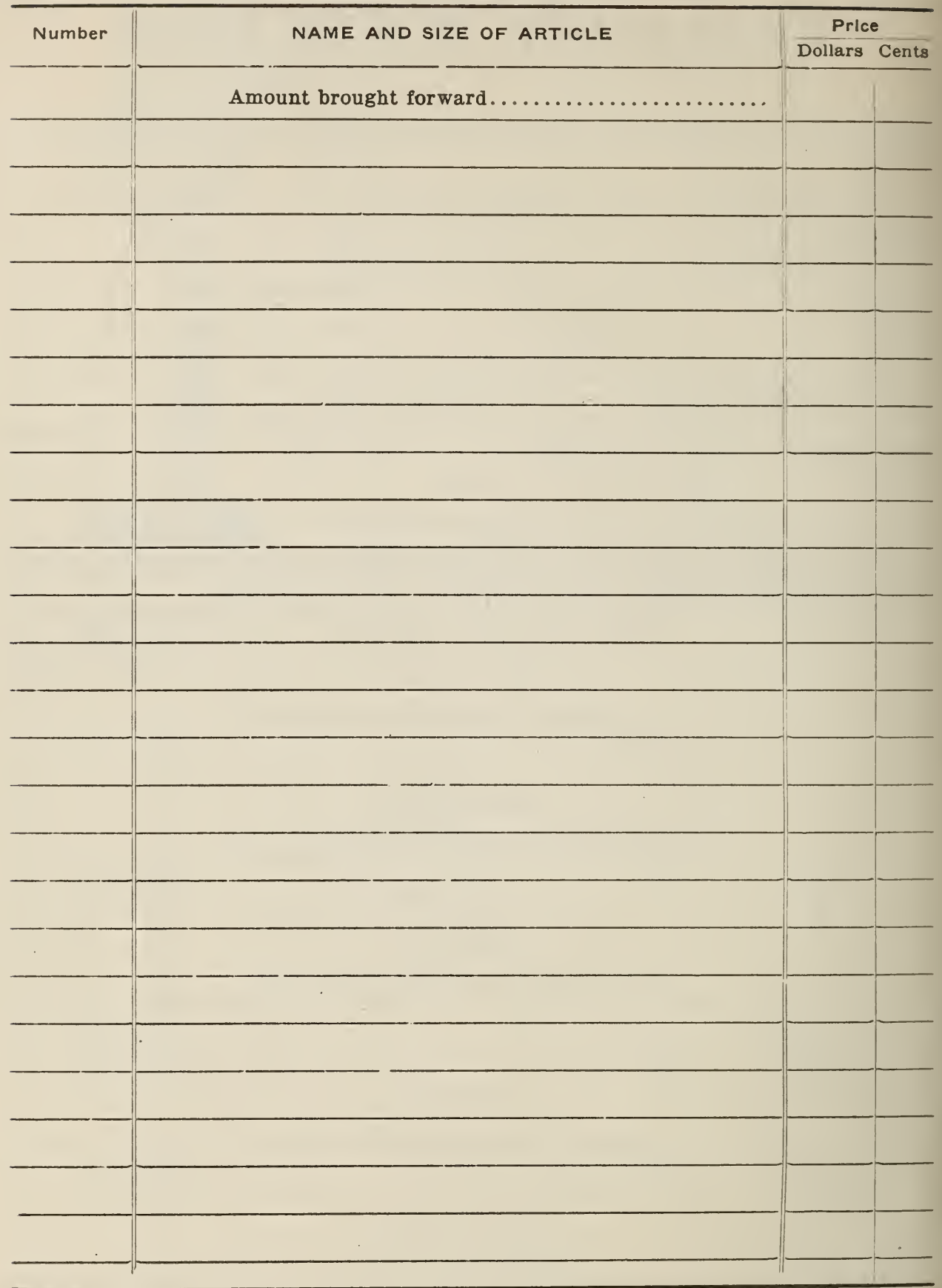




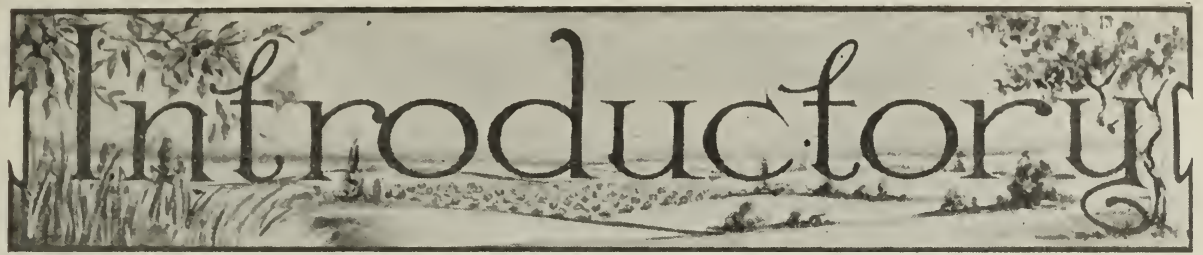

We herewith present you with our thirty-first annual catalogue, and wish to thank you for your liberal patronage in the past and trust that our manner of doing business with you has been satisfactory; and we shall be pleased to have your name upon our order books for 1914.

\section{WHAT WE DO}

We cultivate our trees in the most thorough manner and dig with the best improved tree digger, thus getting good length of roots.

We guarantee all trees, vines and plants to be in a good, healthy and growing condition when they leave our packing rooms.

In packing we use paper lined boxes or bales, using plenty of wet moss and straw, thus preventing stock from becoming dry in transit; we make no charge for bales or boxes.

While we take the best of care in filling orders with stock true to name, should a mistake occur we will be responsible only for the original cost of the stock.

We usually commence shipping in the fall, October 15th, and in the spring, about March 10th. We can, however, ship a greater portion of our stock any time during the winter from our frost-proof cellars; by this plan we can accommodate our cuustomers who live in the South.

On receipt of an order we notify the customer at once by card; if after a reasonable length of time you do not hear from us, write us again; sometimes letters go astray.

In filling orders we send varieties called for as far as possible; for those varieties we are out of we substitute others in their place equally as good, unless you write us not to substitute.

We ship over the St. Joseph \& Grand Island, the C., R. I. \& P., and the B. \& M. railroads; over the United States, Wells-Fargo and Adams Express companies.

\section{TERMS}

In ordering, always give age or size and price of stock wanted; please be very particular in writing your name and address plainly.

Send cash with order, or good bank reference; if you wish stuck sent C. O. D. by express, send one-fourth cash with order; we will then ship it and you can pay balance due to your express agent on receipt of stock.

All remittances should be made payable to C. M. Hurlburt, Manager; send by Postoffice or Express Money Order, Bank Draft, Check or Registered Letter. For amounts less than one dollar you may send one and two-cent stamps.

\section{Our references are First National Bank, or R. G. Dun \& Co.}




\section{SPECIAL OFFERS}

We sell j trees at 10 rates, 50 trees at 100 rates, 500 trees at 1,000 rates.

On all cash orders, at prices in this catalogue, sent us before March 1, 1914, we will allow 5 per cent discount. This offer is to induce you to order carly.

We prepay the freight to any railroad station in the United States, on single or club orders, for plants or trees amounting to $\$ 10.00$ or more, provided the full amount of the order is sent before shipment is made; should you prefer to have a $\$ 10.00$ order or more sent by express we will prepay as much on the expressage as the freight would amount to.

Sometimes our railroad agents here fail to collect enough freight charges from us on prepaid shipments; should your agent require you to pay additional charges in such a case, send us the receipt he gave you, and we will return the money to you.

Parcel Post-The postage upon plants and trees is 8 cents per pound, the parcel post law did not lower the postage upon this class of goods but did increase the weight that could be sent in one package from four to eleven pounds. Packages must not be larger than 72 inches, counting the length and distance around them. Should you want an order sent by mail kindly include postage when remitting.

If you do not want enough trees for your own planting to secure prepaid freight, get some of your friends to club with you and we will tie and label each order separately and ship all together in one package and prepay the freight charges as provided above.

\section{INSTRUCTIONS TO PLANTERS}

Never buy trees of a traveling tree agent; as a rule they are not trustworthy, and will charge from two to ten times what the tree is worth.

Buy direct from some reliable nursery, or from a local nursery agent that you know to be honest. By this plan you will save money and have a source of redress in case there is anything wrong with your order.

It is a good plan to send in your order early, while the nursery's list of varieties is complete. Another thing, if you wait until late in the season, chances are that you will be so rushed with work that you will neglect to order at all, and thus lose a year's growth on your orchard.

As soon as trees are received the boxes or bundles should be unpacked and the roots of the trees soaked in a barrel or tank of water for twenty-four hours before planting; don't leave them in the water longer than this. If you are not ready to plant at once, they may be heeled in moist earth well packed around the roots.

In preparing ground, plow deep and pulverize the soil well before planting. Dig holes large enough so that roots of trees will have plenty of room; in planting, fill holes two-thirds full of loose soil, working it well among the roots as put in, then firm as solid as you can with the foot; fill remainder of hole with water; after it has soaked away fill up the hole with loose earth and do not firm it.

To heel-in trees in the fall for spring planting, select a spot where water will not stand after rains, make an incline of earth the length of the trees, the lower edge of which should be a foot below the surface of the ground, and the upper edge six inches above the surface. Now put the trees two inches apart on the incline with roots down; with a spade commence at lower edge of incline and dig out enough earth to cover trees all over; firm solid around the roots. You can now put in another layer of trees and proceed as before. See that the roots of last layer are covered at least one foot deep; if earth is not wet it shonld be well watered. 


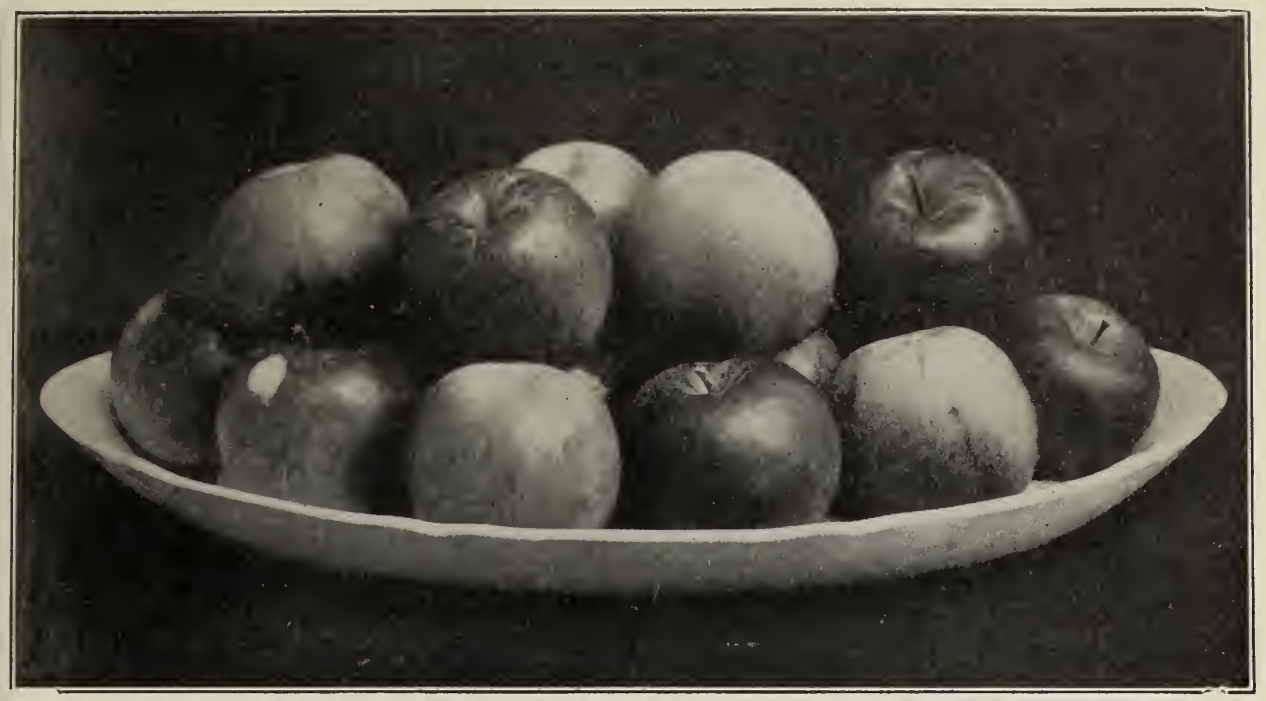

\section{Apples}

The first fruit in importance is the apple. Its period of ripening, unlike that of other fruits, extends nearly or quite through the year. By making judicious selections of summer, autumn and winter sorts, a constant succession can easily be obtained of this indispensable fruit for family use.

If apples are planted at the rate of fifty trees per acre, rows of peach trees can be planted between the apples, which, growing more quickly than the apple trees, soon protect them from winds, and thus prove a great benefit to them. After eight or ten years of productiveness, as the space is needed for the apples, the peach trees may be removed, leaving the orchard better for the protection, and at the same time having yielded the planter a large return for his outlay and labor.

We would advise you in planting an apple orchard to select those varieties which have proven hardy and productive in our western country. We give a brief description of varieties which we consider the best suited for Kansas and Nebraska,

5 to 7 feet, 3 years, extra fine trees $\ldots \ldots \ldots \ldots \ldots \ldots \ldots \ldots \$ 0.20 \quad \$ 1.80 \quad \$ 16.00$

4 to 6 feet, 2 years, well branched $\ldots \ldots \ldots \ldots \ldots \ldots \ldots \ldots \ldots \ldots .15 \quad \begin{aligned} & \$ 1.40 \\ & 13.00\end{aligned}$

3 to 4 feet, 2 years, well branched $\ldots \ldots \ldots \ldots \ldots \ldots \ldots \ldots \ldots \ldots . .11 \quad 1.00 \quad 9.0 \%$

2 to 3 feet, 2 years, partly branched ..................

\section{Summer Apples}

Carolina Red June-Tree hardy, upright, early bearer, shoots slender, foliage dark, color red, almost black in sun, fruit medium, form variable, surface smooth with minute dots.

Duchess of Oldenburg - Tree rather poor in nursery, but has proven one of the best for the North; fruit large, surface smooth, waxen yellow ground covered with bright carmine stripes; sour; one of the very best for cooking; very productive. August.
Other Varieties - Early Harvest, Red Astrachan, Sweet June and Yellow Transparent.

\section{Fall Apples}

Wealthy-An apple of fine appearance and quality, an early and profuse bearer; a good market apple of its season; tree hardy, its chief fault is killing itself by its early and excessive bearing; in size and beauty it equals Baldwin and is a better dessert apple.

Grimes' Golden-Tree upright and hardy, 
fruit full, color golden yellow when ripe, medium to large; quality subacid, mild and melting; valuable in any orchard.

Maiden's Blush-Rather large, oblate, smooth, regular, with a fine, evenly shaded red cheek or blush on a clear pale yellow ground; flesh white, tender, sprightly, with a pleasant, sub-acid flavor; bears large crops. August and September.

Other Varieties - Rambo and Wolf River.

\section{Winter Apples}

Ben Davis-(New York Pippin)-Fruit medium to large, round, skin yellowish, splashed and striped and almost covered with red, flesh white, tender, moderately juicy, sub-acid, an excellent variety, tree very hardy, a free grower, coming into bearing early and very productive; it blooms late in the

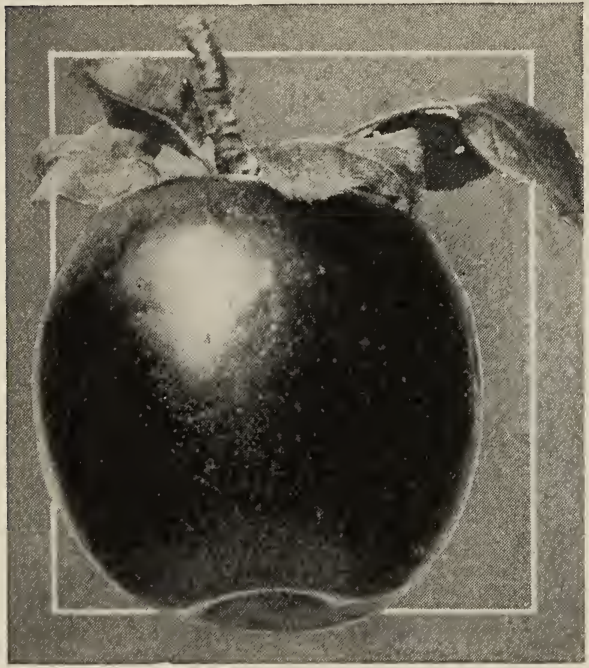

Jonathan spring, thereby often escaping late frosts; very popular in the West and Southwest. December and March.

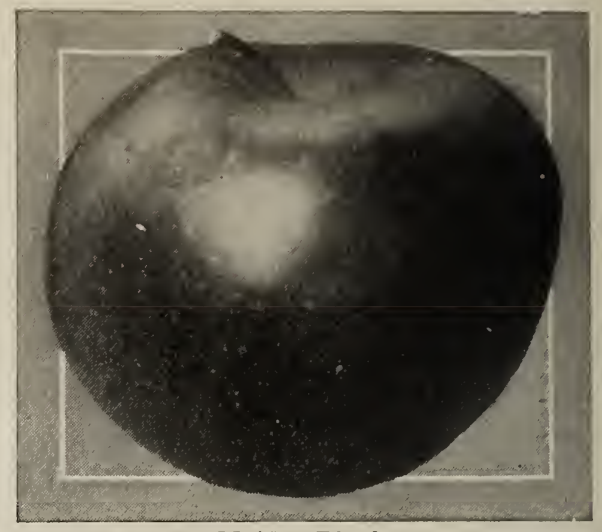

Maiden Blush

Jonathan-Beautiful tree, good grower, fruit full medium, fair producer, color dark, shaded to almost black in sun, fruit drops in dry season. November and December, but can be kept until April.

Winesap-Too well known to require a description. Tree hardy almost wherever planted, early bearer and profitable; tree inclined to overbear, causing the fruit to be undersized; color red, sorretimes almost black; flesh almost yeliow, firm and crisp; one of the best. Nivember to May.

Missouri Pippin-Tree resembles a seedling, good grower, foliage dense, fruit early, very productive; fruit medium, surface smooth, shaded, mixed striped red; flavor sub-acid. very good; season, December to March.

Other Varieties-Tallman Sweet, Northwestern Greening, Mammoth Black Twig, Gano and McIntosh Red.

\section{Vaughn's Seedless Apple}

This remarkable apple tree was found by one of our local agents in Vermillion County, Ind., and we have secured the sole right to propagate and sell it.

On the opposite page we have a cut of this apple, showing the open calyx.

Now we do not claim that this is the largest apple known, for there are many varieties just as large, nor is it the best flavored apple, for there are others just as good, but there are none so sure to bear a crop each year, and few that will keep as well, and upon the strength of the above statements we recommend it to cur customers. 


\section{THE FAIRBURY NURSERIES, FAIRBURY, NEBRASKA}

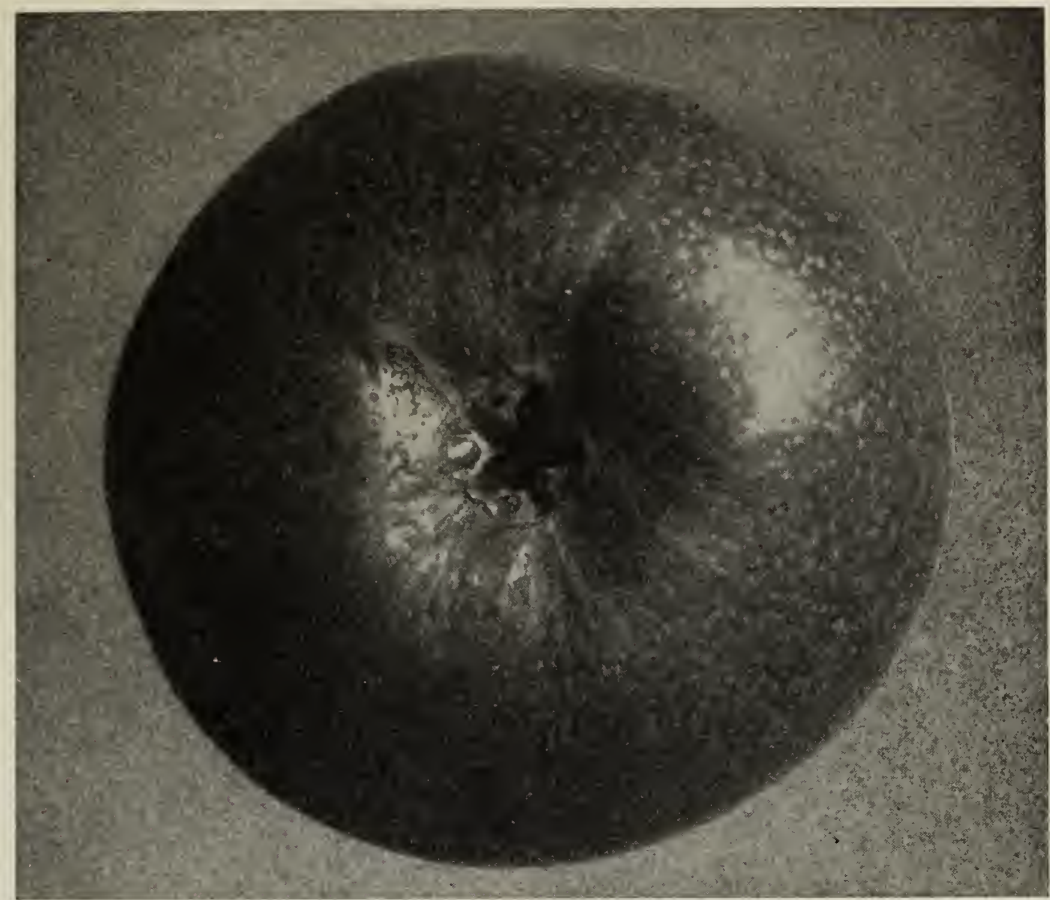

Vaughn's Seedless Apple

Why is it that an apple tree will bear a heavy crop of fruit one year, and then bear few or no apples for one to three years afterward? You have all noticed this; you will say that the tree in producing and maturing the heavy crop of fruit, robbed itself of so much vitality that it was not able to produce fruit the second or third year; that it had to have time to recuperate and grow new wood and fruit buds before it could produce again; this we will admit is the correct theory; but did you ever stop to consider what portion of the apple took the vitality from the tree? Is it the skin or flesh? No, for they are composed mostly of water and the tree can produce them as easily as it can leaves, without loss of strength.

It's the seed of the apple, and nothing else, that robs the tree of its strength and causes it to produce only two years out of five. In Vaughn's Seedless Apple we have gotten rid of the element that produces barrenness, and by planting this variety we can raise apples every year.

Description-The fruit is about the size and shape of the Winesap; flesh firm and yellow, like the Russet, with a flavor similar to the Rambo; nearly red in color, with small yellow dots, and will keep until May.

The tree has no bloom for late frosts to destroy, but the fruit is set in the closed bud; the fruit has a large open calyx which is an advantage over all other apples, for in spraying you can easily get the mixture with its poison into the calyx where it will be waiting for the pesky codling moth when it makes its appearance.

Trees will be shipped to our customers with a sealed tag attached to each tree, and no tree is genuine without this tag.

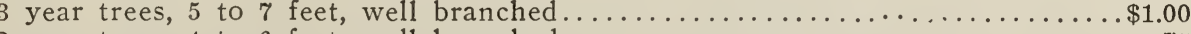

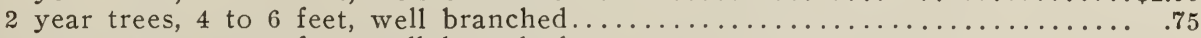

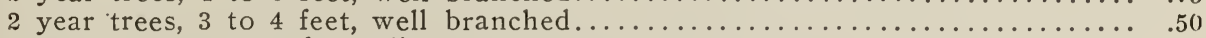

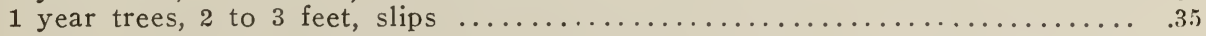


Winter Banana-Here we have a novelty which, while new yet, has been proved to have a high degree of merit. fruit, shaded and marbled with bright crimson. Flesh lemon-yellow, fine It is a large, beautiful, golden yellow

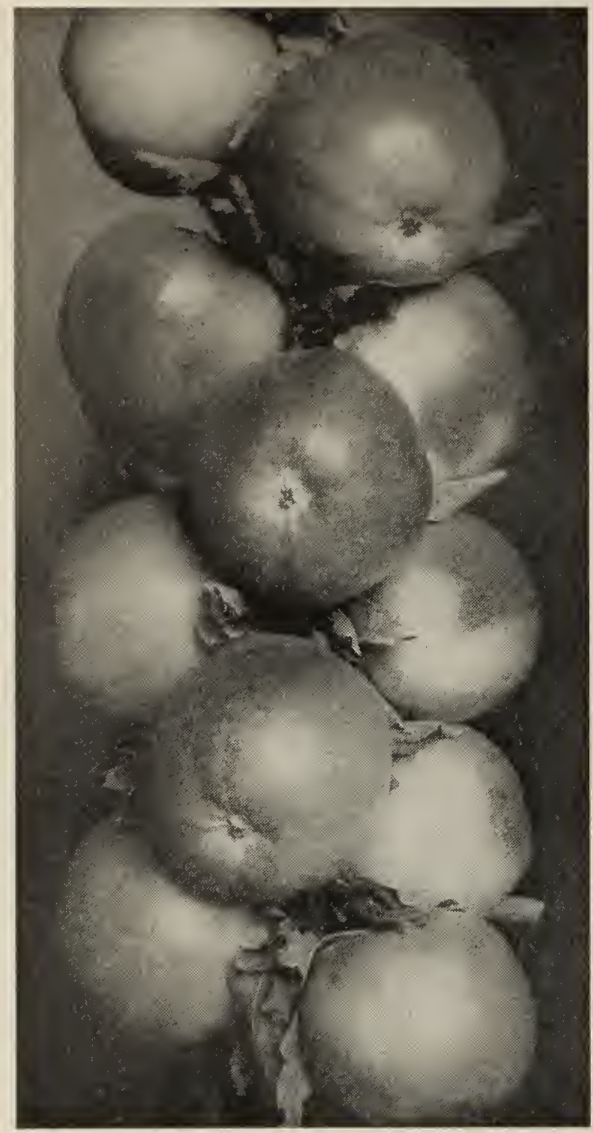

Winter Banana grained, with a rich, aromatic, sub-acid flavor. The name is no mistake, for as you eat the apple you are conscious of a delightful banana perfume. The fruit keeps well into spring, attaining during the last winter months the yellow of burnished gold which, with its share of crimson, makes the Banana apple so attractive. The fruit, so far as we have observed it, grows very uniform, and every apple a good one -one as good as another. Fruit roundish, inclining to conical, stalk $3 / 4$ inch long, cavity moderate, and very showy in appearance. Ours is pedigreed stock, budded direct from bearing trees, and will be sure to bear young and give good satisfaction.

Each

5 to 6 foot trees.............\$0.35

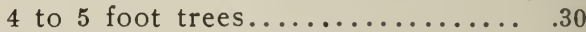

3 to 4 foot trees.............. .25

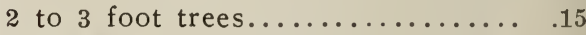

Bismarck-In respect to its early fruiting habit, the most remarkable apple ever introduced; 1-year grafts frequently produce fruit, and 2-year trees seldom fail. Has fruited in many sections of the United States this season; we hear only words of commendation. Originated in New Zealand; has been tested in nearly every apple country and promises to succeed wherever apples can be grown, proving healthy, hardy, productive and without a rival in its early fruiting quality. Tree of short, stocky growth, makes beautiful specimens grown in pots for decorative purposes. Fruit large, handsome yellow, sometimes shaded red cheek; flesh tender, pleasant sub-acid, good for dessert, superior for cooking; will keep well into winter. Each

5 to 6 foot trees............\$0.50

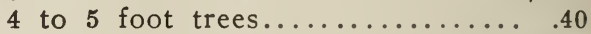

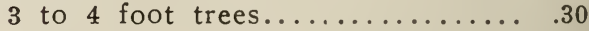

2 to 3 foot trees.............. .20

\section{Crab Apples}

The improvements in the varieties of Crab Apples have kept pace with the other kinds of fruit. A few years ago it was only thought fit for cider, jelly and preserves, but there are varieties now that command good prices in the market for dessert purposes; especially is this true of the Whitney. Besides being useful they are very ornamental when in bloom and when burdened with their load of highly colored fruit.

5 to 6 feet, 3 years, fine trees $\ldots . .$.

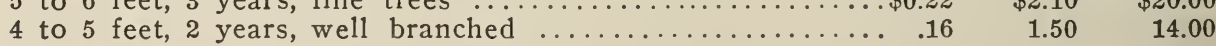

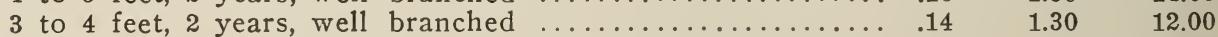

2 to 3 feet, 2 years, partly branched ................... $10 \quad .90 \quad 8.00$

Plant and prune them the same as apples. We give a description of varieties in the following that we consider among the best: Hyslop, Whitney, Golden Beauty and Transcendent. 


\section{Pears}

Pears being upright growers, may be planted twenty feet apart, each way. They should be trained to branch as near the ground as possible; the first four years' planting, the top leaders should be cut out and thus compel them to form a bushy top.

Dwarf pears come into bearing four years after transplanting and standards not until the eighth year.

Per 1 Per 10 Per 100

5 to 7 feet, Standard, 3 years, extra fine............. $\$ 0.32 \quad \$ 3.00 \quad \$ 28.00$

4 to 6 feet, Standard, 2 years, well branched...............25 $25 \quad 2.25 \quad 20.00$

3 to 4 feet, Standard, 2 years, branched..................20 $\quad 1.75 \quad 15.00$

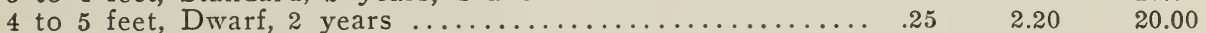

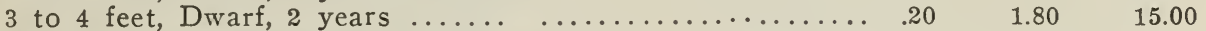

2 to 3 feet, Dwarf, 2 years $\ldots \ldots \ldots \ldots \ldots \ldots \ldots \ldots \ldots \ldots \ldots . .18 \quad 1.40 \quad 12.00$

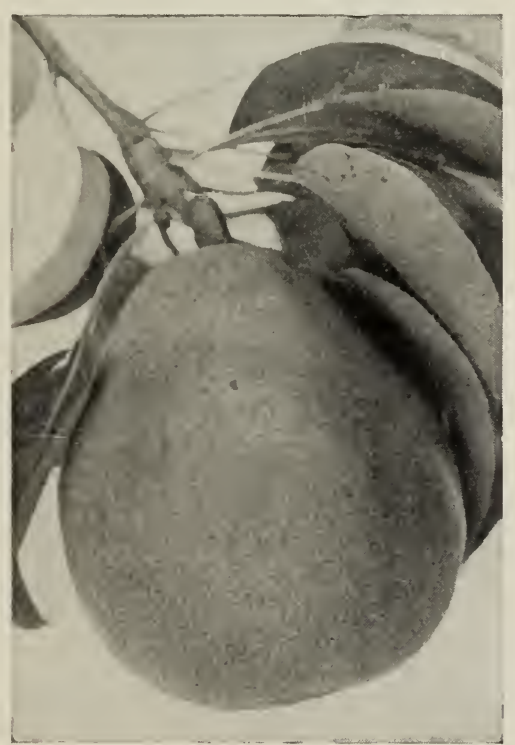

Kieffer Pear

Bartlett-Large size with often a beautiful blush to the sun; buttery, very juicy and highly flavored; bears early and abundantly; very popular. August.

Clapp's Favorite-Very large, yellowish green to full yellow when ripe, marbled with dull red in the sun and covered with small russet specks, vinous, melting and rich; season, July.

Kieffer's Hybrid-The pear was raised from seed from Chinese Sand Pear accidentally crossed with the Bartlett or some other kind grown near it. Tree has large, dark, green glossy leaves, and is of itself very ornamental; is an early and very prolific bearer; the fruit is of good quality, wonderfully showy and is valuable for the table and market; it never rots at the core, and is as nearly blight proof as is possible for any pear to be. September and October.

Duchess d'Angouleme--Very large, dull greenish yellow streaked and spotted with russet, flesh white, buttery and very juicy, with rich and very excellent flavor, on the quince, to which stock this variety seems well adapted; it is always fine, the large and fine appearance of this fruit makes it a great favorite. September and October.

Seckel--Small, skin rich yellowish brown when ripe, with a dull brownish red cheek, flesh very fine grained, sweet, is exceedingly juicy, melting, buttery, the richest, highest flavored pear known. August and September.

Flemish Beauty - Is large, beautiful, juicy, melting, rich and fine, good bearer, is hardy everywhere. August and September.

Lawrence-Is rather large, yellow, covered with brown dots, flesh whitish, slightly granular, somewhat buttery, with a rich aromatic flavor, unsurpassed among the early winter pears, succeeds well on the quince, ripens with little care, should be in every orchard, tree healthy, hardy and productive. November and December.

\section{Nectarine Trees}

The Nectarine has a smooth skin like the plum, and requires the same treatment for curculio. It is like the peach in other ways and requires the same culture. The following varieties are best: 
Boston-The largest and most beautiful variety known. Deep yellow, mottled and shaded with red, flesh sweet, with a peculiarly pleasant flavor; free stone. Tree hardy and productive. September.

Downton-Large pale green, with violet red cheek, flesh rich and delightful; free from stone. August.

3 to 4 foot trees....................................... $\$ 0.25 \quad \$ 2.00$

\section{Budded Peaches}

The peach tree requires a moderately rich, well drained soil, and in order to preserve the continued healthy growth of the tree and thus cause it to produce well matured fruit its branches should be headed in each year.

Peach trees when planted alone should be set twenty feet apart, or they may be planted between apple trees. Plant them deep enough so that the crook in the tree where they were budded is covered witn earth.

In Nebraska we cannot expect a full crop of peaches each year, owing to our cold winters, which kill the bloom buds, but if you only get a full crop once in three years, they will pay you better than any other fruit crop that can be raised in Nebraska, cherries and strawberries excepted.

\begin{tabular}{|c|c|c|c|}
\hline 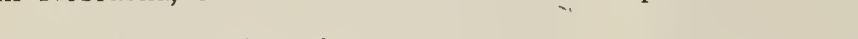 & Per 1 & Per 10 & Per 100 \\
\hline to $6 \mathrm{f}$ &.$\$ 0.20$ & $\$ 1.70$ & $\$ 16.00$ \\
\hline to $5 \mathrm{fe}$ & .14 & 1.30 & 12.00 \\
\hline o $4 \mathrm{f}$ & .11 & 1.00 & 9.00 \\
\hline $3 \mathrm{fe}$ & $\begin{array}{lr}. \quad .09\end{array}$ & .80 & 7.00 \\
\hline 2 & $\begin{array}{ll}\text {.. } & .07\end{array}$ & .60 & 5.00 \\
\hline
\end{tabular}

Champion-Many specimens have measured 10 inches in circumference. The flavor is delicious, rich, sweet and juicy; surpasses all other early varieties; skin creamy white with red cheek, strikingly handsome, It is hardy, productive, the largest size, highest flavor and best shipper of the early peaches. Ripens in early August.

Alexander Early-Large size, well grown specimens measuring eight inches in circumference, handsome and regular in form with deep naroon shade, covered with the richest tint of crimson, rich and good in quality, with a vinous flavor; adheres to the stone; should remain on the tree until fully ripe. Late in June.

Crawford's Early-This beautiful yellow peach is highly esteemed for market purposes. Fruit very large, oblong; skin yellow with fine red cheeks; flesh yellow, juicy, sweet, excellent, productive, free. Last of July.

Crawford's Late-Fruit of the largest size; skin yellow with dull red cheek; flesh yellow; productive, one of the best. Last of Augisst and September.

Elberta-A Georgia cross between Crawford and Chinese Cling; very large, well colored; all things considered, the finest yellow freestone in cultivation; no one can go amiss by planting it; fruit perfectly free from rot, and one of the most successful shipping varieties. August 20.

Other Varieties-Mountain Rose, Crosby, Triumph, Salway, Bokara and Chinese Cling.

\section{Seedling Peaches}

Our seedling peaches are grown from seed taken from freestone and the trees will produce fruit of good quality. We have no names for them.

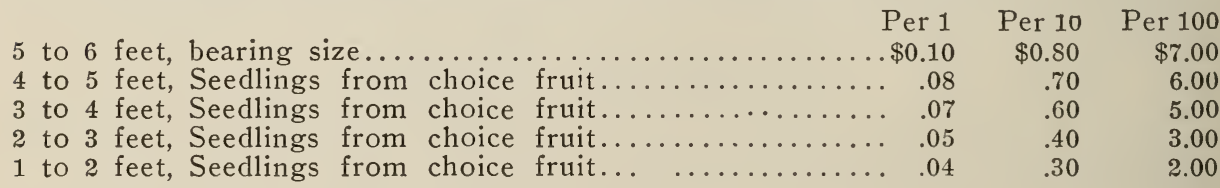



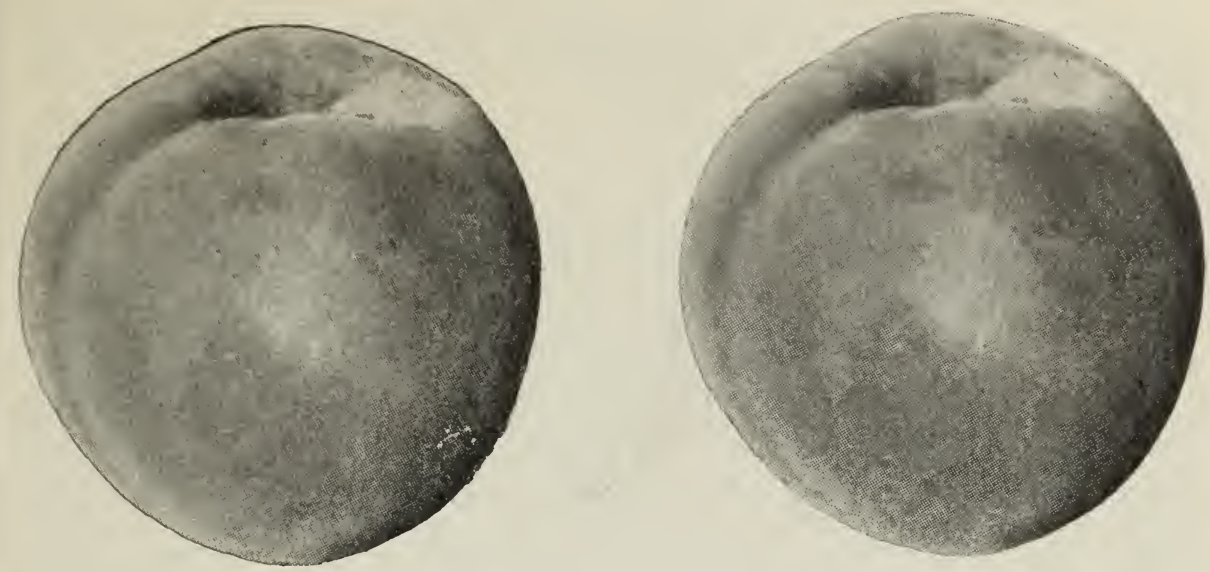

Famous Stewart Peach

Stewart Peach-This variety originated in Utah several years ago, and we have found it to be a first-class peach; it is a very strong-growing tree, fruit extra large, color yellow, very juicy with a firm skin, which makes it a good shipper.

Stewart Peach, budded, 5 to 6 feet...................... \$0.35 $\$ 3.00$

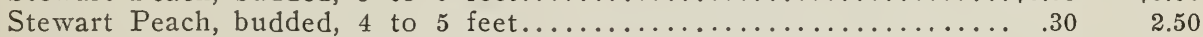

Stewart Peach, budded, 3 to 4 feet....................... .25 2.00

Stewart Peach, budded, 2 to 3 feet.......................20 .20 1.50

\section{Plums}

The plum does best on a rich, well drained soil, the trees should be planted sixteen feet apart, and it is well to plant several varieties together, for they seem to produce larger crops in that way than where a single variety is planted alone. Prune them so they will be low headed, and thus protect the fruit from wind storms which sometimes play sad havoc with the fruit when commencing to ripen.

Per 1 Per 10 Per 100

5 to 6 feet, 3 years, fine trees $\ldots \ldots \ldots \ldots \ldots \ldots \ldots \ldots \ldots . \$ \ldots .40 \quad \$ 3.50 \quad \$ 32.00$

4 to 5 feet, 2 years, well branched $\ldots \ldots \ldots \ldots \ldots \ldots \ldots \ldots \ldots .30 \quad 2.50 \quad 22.00$

3 to 4 feet, 2 years $\ldots \ldots \ldots \ldots \ldots \ldots \ldots \ldots \ldots \ldots \ldots \ldots \ldots .25 \quad 2.00 \quad 18.00$

2 to 3 feet, 2 years, partly branched $\ldots \ldots \ldots \ldots \ldots \ldots \ldots \ldots .20 \quad 1.50 \quad 12.00$

Abundance - Of medium size, large when thinned, amber with markings of red, juicy, sweet, of good quality when well ripened. May be picked when it begins to color, will keep a long time; color well and be almost as rich and sweet as if ripened on the tree-a strong point for market growers. Usually the fruit must be thinned to prevent overbearing. August.

Burbank-The best of all the Japan sorts of plums, nearly globular, clear cherry red, and with a thin lilac bloom. The flesh is deep yellow color, very sweet, with a peculiar and very agreeable flavor, tree vigorous, with strong, upright shoots, large, bruad leaves, commences to bear usually at two years. It blooms late and consequently more liable to escape the late spring frosts.

Othe- Varieties-Wolf, Lombard, Wild Goose and German Prune. 


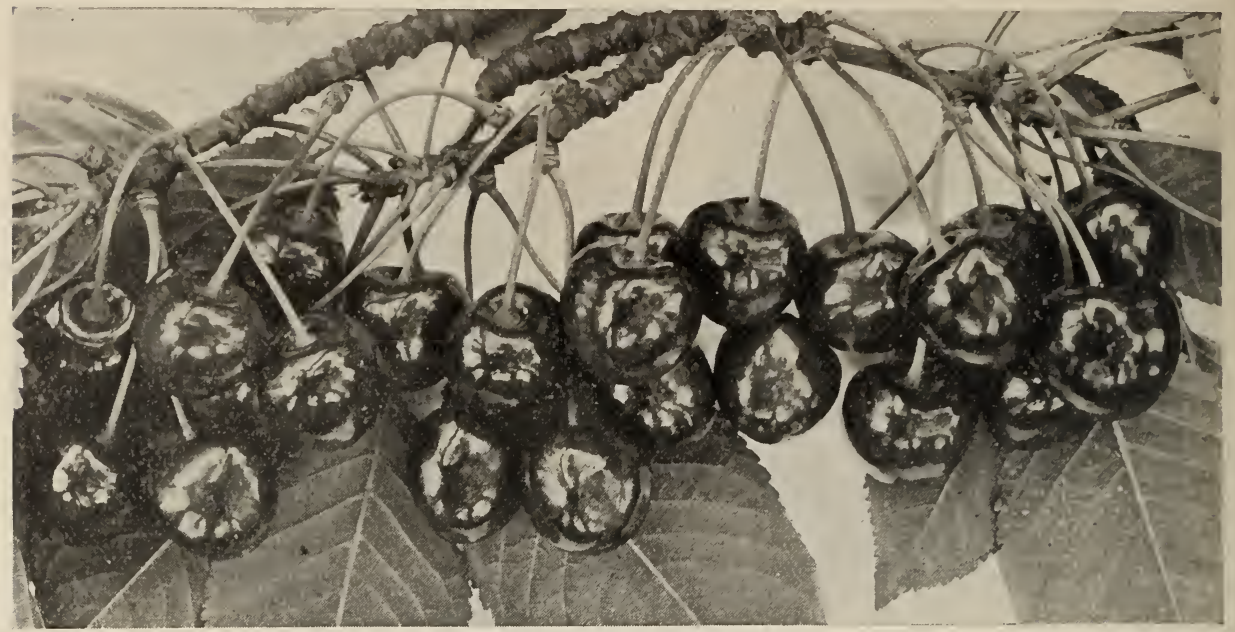

Large Montmorency

\section{Cherries}

A great deal of attention is now given to the growth of cherries in the West, and no well planted home orchard is complete without its proportion of cherry trees, and it is one of the most prolific of garden fruits. It will succeed in any kind of soil that is not wet.

It may be planted near the street, or used to line avenues as an ornament, and it will at the same time produce an abundance of delicious fruit. This may be eaten out of hand, preserved, or it will find a ready market at highly profitable prices, for shipping, canning, etc.

Our cherry trees are budded on Mahaleb cherry stocks, which do not sprout from the roots. Care must be taken in planting that the trees are not planted too deep; one inch deeper than where budded is deep enough; should they be planted deeper than this, the tree will be liable to throw out roots above where budded, and these roots if broken will throw up sprouts or suckers.

Plant trees twenty feet apart, keep the main leaders headed back the first two or three years after transplanting; by so doing you will have fine, bushy tops near the ground, which will be of great advantage in picking the fruit.

5 to 7 feet, 4 years, extra large............. $\$ 0.50$

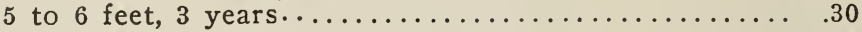

$\operatorname{Per} 10$

$\$ 4.50$

2.70

Per 100

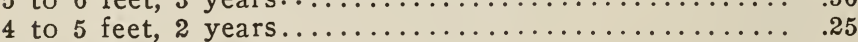

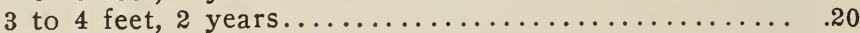

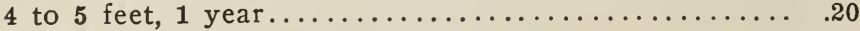

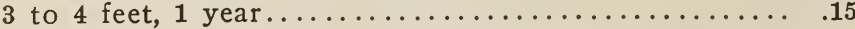

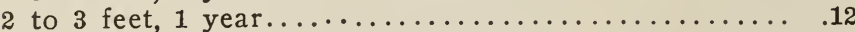

2.20

1.70

1.80

20.00

Dye House-This variety partakes both of the Murillo and Duke, wood and fruit; a very early and sure bearer; ripens a week before Early Richmond, of better quality and quite as productive. May and June.

Early Richmond-(Kentish Virginian, or Early May)-Medium size; dark red; melting, juicy, sprightly, acid flavor. This is one of the most valuable and popular of cherries and is unsurpassed for cooking purposes, and is exceedingly productive. First of June.

Large Montmorency-A large, red, acid cherry, larger than Early Richmond and fully ten days later. Middle of June.

English Murillo-Tree slow grower but very abundant bearer; ve"r hardy, fruit slightly conical, dark red, almost black when fully ripe. Three weeks later than Richmond; most prolific. 
Ostheim-A hard cherry from Russia. It has been tested in the severest winters of Minnesota, and has been found perfectly hardy. Fruit roundish, large, ovate; skin red, dark at maturity; stems long; flesh liver color; tender, juicy, almost sweet.

Black Tartarian-Large, juicy, rich, mild and sweet, vigorous and productive. Early.

Governor Wood-Large, yellow, shaded with light red, juicy, very delicious. A vigorous grower and very productive. Early Sweet.

Baldwin Cherry-The tree is an upright grower, more inclined to be round than otherwise; a very rank, vigorous grower, leaves rather broad; bloom pure white, which turns to a pink color, similar to the hydrangea; fruit very large, almost perfectly round, very dark, yet almost transparent; flavor slightly sub-acid, yet the sweetest and richest of the Murillo type; stems rather large, of medium length, more inclined to grow in pairs than in clusters. It is remarkable for earliness, vigor, hardiness, quality and productiveness. It is a tree to command attention, and is so distinct as to attract comments from any upon seeing it, without knowing its superior merits.

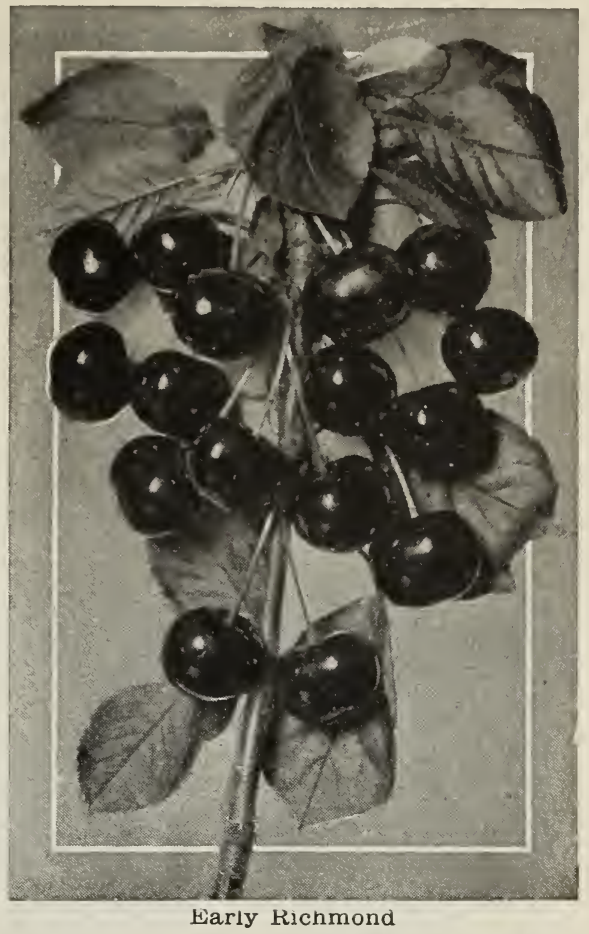

Baldwin Cherry, 5 to 6 feet...................... Per 1

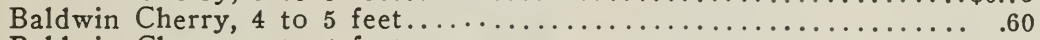

Per 10

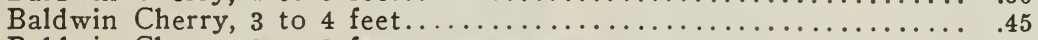

$\$ 6.00$

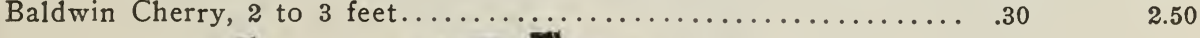

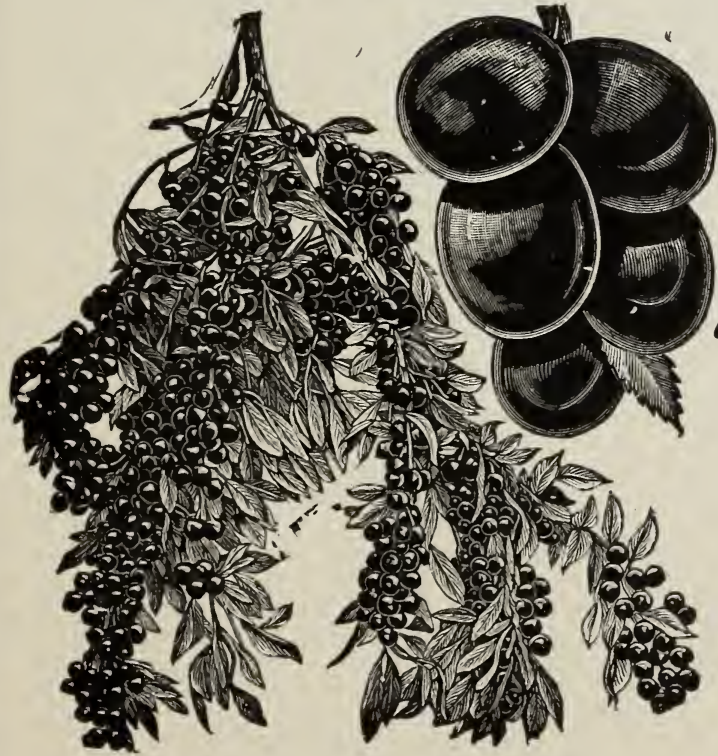

\section{Rocky Mountain Cherry}

This is a novelty and a very profuse bearer, but the fruit is not as good as our leading sorts; grows in the form of a bush, and is as hardy as Wyoming sage brush. It has stood 45 degrees below zero and unharmed in limb or fruit bud; fruit about as large as English Murillo; cherry black when fully ripe; acid and very good for pie or wine. Season, July.

2 -foot trees, 15 cents each; 10 trees, $\$ 1.00$. 


\section{The Compass Cherry Plum}

The Compass Cherry-Plum originated with H. Knudson of Springfield, Minn., and is believed to be a cross between the Western Sand Cherry and the Miner Plum. Its habit of growth is like the Miner, while the leaf, twig and bark very much resemble the Sand Cherry. It is a strong grower, and makes a very fine orchard tree. Fruit about an inch in diameter, and is as much a plum as it is a cherry. The shape is oblong and slightly flattened. The pit is between the ordinary American plum and Early Richmond pit in shape and size. It has a flavor peculiar to itself, very palatable and rich. An immense and early bearer. Tree perfectly hardy as far north as Manitoba.

$$
\text { Per } 1
$$

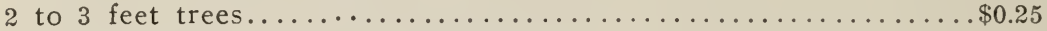

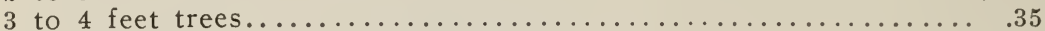

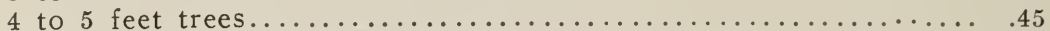

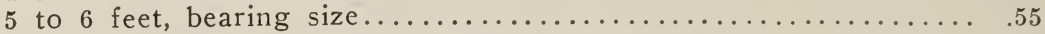

\section{Quinces}

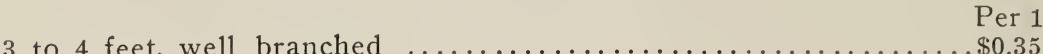

Per 10

$\$ 2.00$

3.00

4.00

5.00

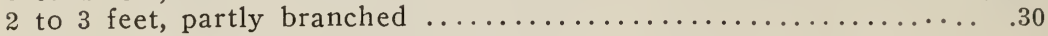

Per 10

$\$ 3.00$

2.50

Apple or Orange-Large, roundish, bright golden yellow; cooks tender and is of excellent flavor. Valuable for preserves for flavoring; very productive, the most popular and extensively cultivated of the old varieties. October.

Champion-Fruit very large, fair and

handsome. Tree very handsome, surpassing other varieties in this respect; bears abundantly while young; flesh cooks as tender as an apple, and imparting an exquisite quince taste and odor to any fruit with which it is cooked. The most valuable of all.

\section{Apricots}

A delicious fruit of the plum species, valuable for its earliness. It bears immense crops. Ripens July and August. Plant the same as peach.

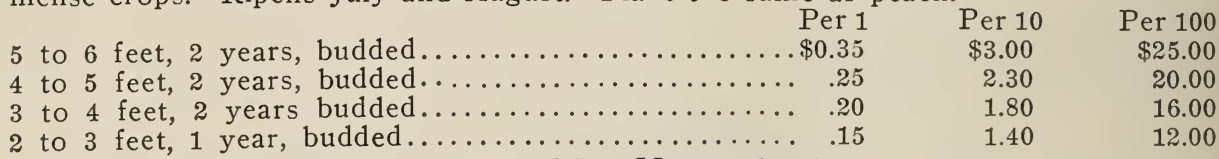

Superb-One of the largest; orange with Moorpark-One of the largest; orange red cheek; firm, juicy with rich flavor; with a red cheek; firm, juicy with a very productive. August.

Royal-Large; yellow with orange cheek; juicy, rich and delicious; a fine variety. Last of July. rich flavor; very productive. July.

Russian Apricot - A new variety of recent introduction; valuable on account of extreme hardiness of trees and fine quality of fruit.

\section{Grapes}

The history of the grape is almost as old as that of man. Vineyards were extensively planted before orchards or collections of other fruit trees were at all common, and today it is one of the most highly appreciated fruits. In its flavor it is hardly surpassed by any other fruit in delicacy and richness, and few or none are more beautiful in the dessert. Any person having a plot of ground ever so small, either in country or city, can find room for one-half to one dozen grape vines. They can be trained up by the side of any building or over a garden fence; but the best and cheapest way to grow them in small or large quantities is on the wire trellis.

Work the ground deep and plant a little deeper than they were in the nursery. Make rows eight feet apart and six to eight feet in the row. Some of them, the tender varieties, would be benefited by laying the vines flat on the ground during the winter, with a light covering of earth or litter. 


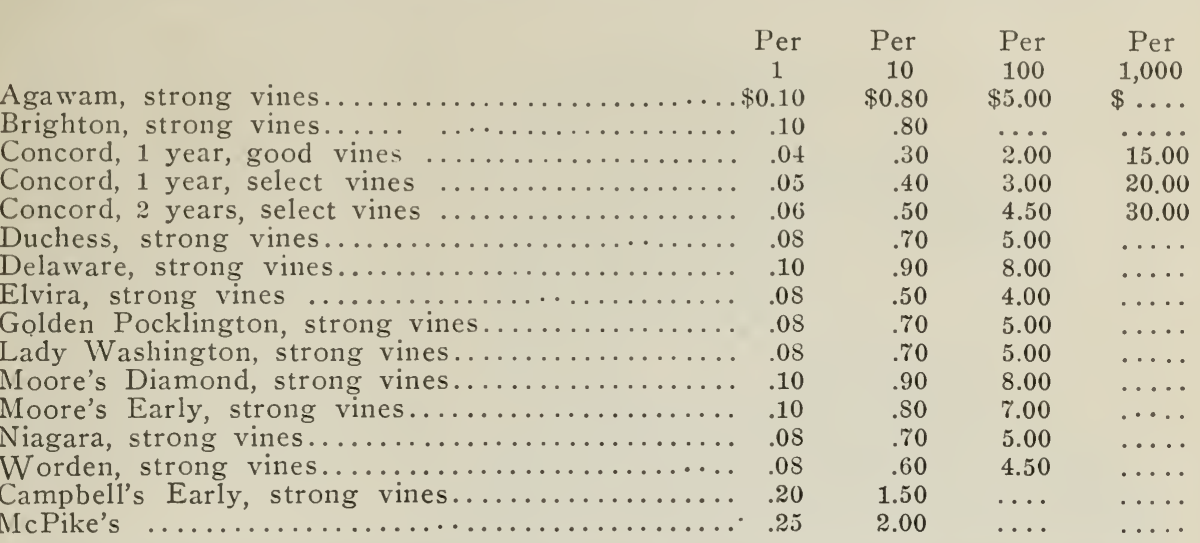

Vines sent by mail for two cents each, extra.

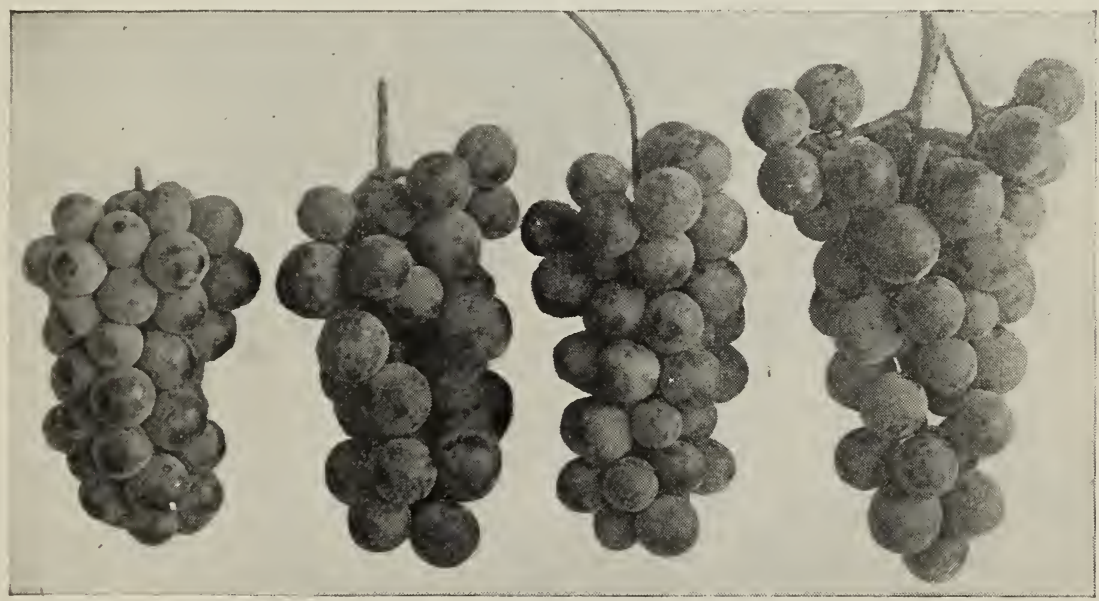

Delaware.

Niagara.

Concord - Bunches large, berries large, round, skin thick and covered with bloom; flesh juicy, sweet. Vine hardy, vigorous and productive, at present the most popular of all our native sorts.

Worden-This variety is a seedling of Concord which it greatly resembles in appearance and flavor, but the berries are larger, the fruit is better flavored and ripens several days earlier. Black.

Moore's Early. A large black grape of the Concord type, the entire crop ripening before the Concord, bunch medium, berries large with blue bloom, flesh pulpy, of medium quality. Vine hardy, moderately productive, better as it attains age. Planted extensively as a market sort.
Agawam.

Brighton.

Agawam-Large, round, early and of great vigor of growth; rich, high, peculiar aromatic flavor, much subjected to disease and too highly flavored, where all its aroma is developed, to be desirable. Red.

Description of the McPike Grape-We have in this new, wonderful grape, great size, wonderful quality, hardy wood and bud, very large leathery leaves. Fruit ripens same season as Worden, which is one week earlier than Concord. This grape ripens evenly, and only has one or two seeds; skin tender and pulp melting. This grape has taken all premiums at all the great state fairs in the fall of 1898 and 1899 wherever exhibited, over all competi- 
tors. Many testimonials could be printed, if space would permit, regarding the success of this wonderful vine.

Campbell Early - The king of grapes.

The best all-round grape on the market. A very strong, hardy vine, with perfect, self-fertilizing blossoms, always setting its fruit well and bearing abundantly. Clusters very large, berries round and of great size, very sweet and rich. The seeds separate easily from the pulp; ripens first of August, but can be kept until December in cold storage; color black, with a light purple bloom.

Delaware-Still holds its own as one of the finest grapes; bunches small, compact, shouldered; berries rather small, round, thin skin, flesh very juicy; without any hard pulp; an exceedingly sweet, spicy, delicious flavor; vine moderately vigorous; hardy and productive. Red.

Brighton-A cross between the Concord and the Diana Hamburg; bunches large, berries of medium size; flesh sweet, tender and of the highest quality; ripens early. Red.

Worden (Black)-This variety is a seedling of Concord, which it greatly resembles in appearance and flavor, but the berries are larger, the fruit is better flavored and ripens several days earlier.

Moore's Diamond - Very hardy, healthy and vigorous; ripens from two to four weeks earlier than Concord. White.

Niagara-A magnificent white grade and very valuable for both garden and vineyard, a rank grower and very productive of beautiful bunches of the largest size; berries large, with tough skin; quality good; ripens with Concord.

Lady Washington-Fruit yellow, tinged with pink, bunches very large, often weighing a pound; vine strong, very healthy.

Golden Pocklington-Is a seedling from Concord; vine hardy, both in wood and foliage; strong grower, called a white grape, but the fruit is a light golden yellow; clear, juicy and sweet to the center, with little or no pulp; bunches very large, sometimes shouldered; berries round, large and thickly set; quality, when fully ripe, much superior to Concord; ripens with Concord.

Elvira-Ripens about with Catawba; a very strong, healthy and robust grower; productive; bunch and berry of medium size; very compact. White.

\section{Currants}

A cool, moist location is best for this fruit, and for this reason it succeeds admirably when planted by a stone wall or fence, being benefited by partial shade. Plant in rows four feet apart and the plants three feet apart in the rows. They should be pruned each year, and all dead wood cut from them. Keep them thinned out so that air can freely pass through them. Currant worms can be destroyed by the use of hellebore. Dissolve an ounce in three gallons of water, and apply with a syringe or small sprinkling can. This can be done with very little expense if performed at the right time. $\quad$ Per $1 \quad$ Per 10 Per 100 Black Naples and Champion, 2 years............\$0.10 $\$ 0.80 \quad \$ \ldots$ Cherry, Red Dutch and Victoria, 2 years............. White Dutch and White Grape, 2 years................... $.07 \quad .67 \quad 50$ Fay's Prolific and North Star, 2 years....................... $.08 \quad .70 \quad 5.00$ Crandall, 2 years $\ldots \ldots \ldots \ldots \ldots \ldots \ldots \ldots \ldots \ldots \ldots \ldots \ldots . .10 \ldots \ldots$

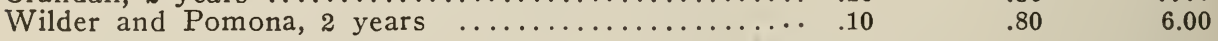

\section{Gooseberries}

In order to produce large, abundant crops of gooseberries, it is necessary to manure heavily and prune closely. The English varieties do not require much pruning. Mildew is prevented by close planting and heavy mulching. Plant 3 to 4 feet each way.

Per 1

Houghton and Transparent, 2 years............ 0.12

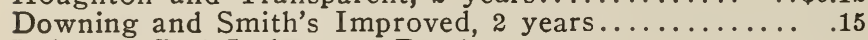

Industry, Red Jacket and Pearl, 2 years........... .20
Per 10

$\$ 1.00$

1.30

1.80
Per 100

$\$ 10.00$

12.00 
Red Jacket-An American seedling of large size, smooth, prolific and hardy, of best quality; has been well tested over a wide extent of territory. A wonderful cropper, with heavy foliage.

Downing - Fruit larger than Houghton; roundish, $1 \mathrm{ight}$ green, with distinct veins, skin smooth, flesh is rather soft, juicy and very good. Vigorous and productive.

Houghton - A medium sized American variety, which bears abundant and regular crops, and never mildews. Fruit smooth, tender and good. Very valuable.

Industry - The best English gooseberry yet introduced, of vigorous upright growth and a greater cropper than any known variety, and much less subject to mildew than other English varieties. Berries of the largest size, one and onehalf inches in diameter, and of the most excellent flavor,

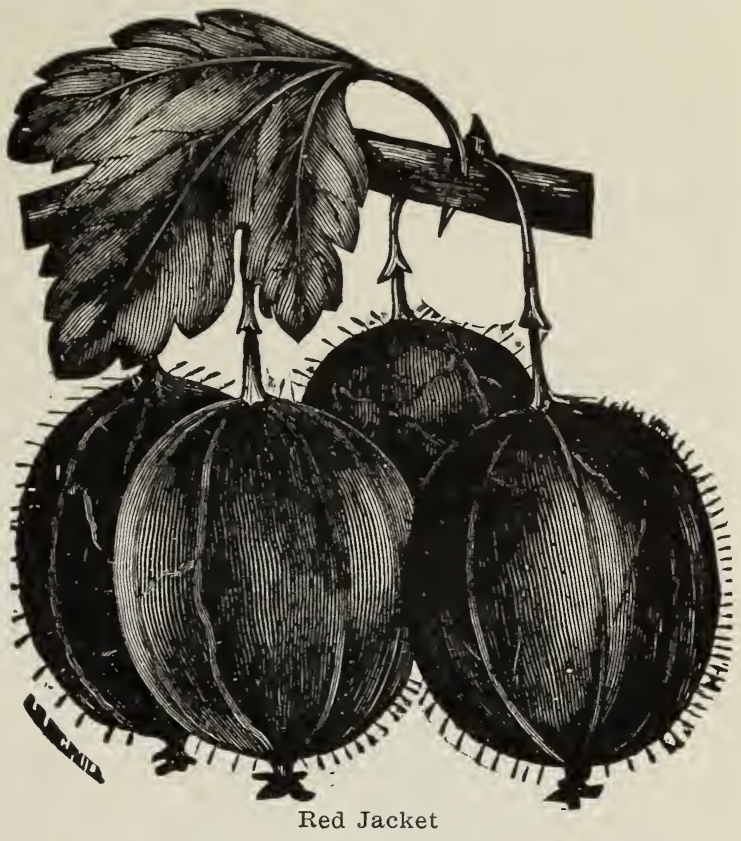
both pleasant and rich; color when fully ripe. Dark red.

\section{Dwarf Service or June Berry}

Grows four to six feet high, bunches out from the ground like currants, resembles the Common Service or Juneberry in leaf and fruit, but the fruit is larger and in color almost black; commences to bear the second year after transplanting, and bears profusely. No farm or garden should be without this most excellent dessert fruit.

12 to 18 inch

Per 1
$\$ 0.10$

Per 10

$\$ 0.75$

1.25

Per 100

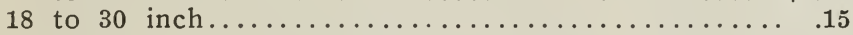

\section{Raspberries}

Should be set in the spring; plant $3 \frac{1}{2}$ feet apart in the row and rows 4 feet apart. Set plants 3 to 4 inches deep, depending on the soil (in heavy clay do not set as deep as on light soil), roots spread out and dirt pressed firmly among them. Give thorough shallow cultivation until last of July, or if you prefer mulch in the row with coarse manure or something of that kind, and keep the ground well stirred between the rows. When the new canes are about two feet high, pinch off the top; this will make the plant throw out side branches and do away with the necessity of tying up. In the spring cut these side branches back to 16 or 18 inches in length. Four or five good canes in a hill are enough. Cut out old canes as soon as through fruiting and burn them.

Per 1 Per $10 \quad$ Per 100

Gregg and Mammoth Cluster, black...........\$0.05

Turner, Cuthbert and Thwack, red............ 05

Kansas, Ohio and Souhegan, black.....................

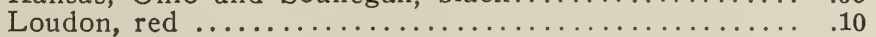

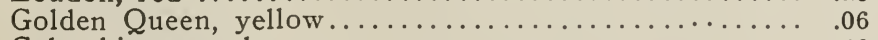

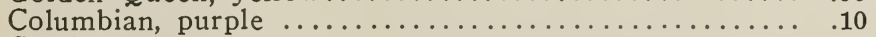

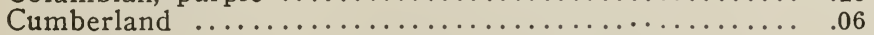

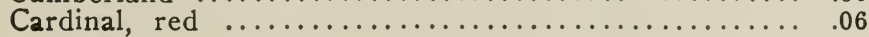

$\$ 0.30 \quad \$ 2.00$

$.30 \quad 2.00$

$.30 \quad 2.00$

$.50 \quad 4.00$

$.50 \quad 4.00$

$.75 \quad 6.00$

$.50 \quad 4.00$

$.50 \quad 4.00$ 


\section{Logan Berry}

Or Raspberry Blackberry-Originated in California in 1884. Supposed to be a cross between a red raspberry and a blackberry. In California for several years it has been grown in quantity for market and has been well tested in Eastern states, Vine is a strong grower, spreading like Dewberry, free from disease; canes large, exceedingly prolific; ripens very early. Fruit size of large blackberries, same form and shape; color bright red, seeds small, flavor combination of blackberry and raspberry; mild, pleasant, vinous, excellent. 20 cents each; 6 for $\$ 1.00$.

\section{Strawberry-Raspberry}

Strawberry Tree-A very beautiful fruit from Japan. Bush from 18 inches to 2 feet in height, entirely hardy and impervious to heat and drought. The berries are larger than the largest strawberries, bright, shining scarlet with an exquisite bloom. An immense yielder, producing regularly and abundantly. It bears the first season and gets stronger and larger each year. All lovers of fruit should give it a trial. It will both surprise and please you. 15 cents each; six for 80 cents.

\section{Blackberries}

In field culture plant in rows 8 feet apart and 3 feet in the rows. In garden culture plant rows 5 feet apart and 3 feet distant in rows. The pruning should be governed by the growth of cane and should be severe. Pinch back the canes in summer when 3 feet high, causing them to throw out laterals.

Cultivate for first season to get plants well established, then the ground between the rows may be mulched enough to keep down all weeds.

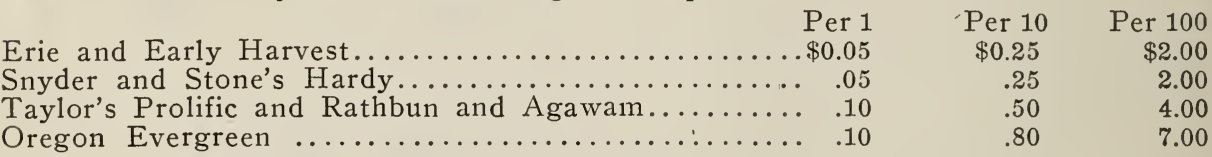

\section{Himalaya Berry}

This berry is a new arrival from the North Slope of the Himalaya Mountains, 6,000 feet above sea level. It is black, but not a blackberry. For many centuries the natives of that country have been making wine of it, and only the invasion by British tropps has brought this delightful, luscious fruit to our civilization. The vine is a vigorous grower, making a growth of 20 to 30 feet in one year, which can be trained on a fence or arbor similar to grape vines. The enormous clusters of large sized berries ripen all summer, making the Himalaya the most productive of any variety known. They have no core and the flavor is sweet, of unusual richness, and when ripe will literally melt in your mouth. For pies, jellies and dessert the Himalaya berry is a perfect success, being ahead of any similar fruit. The severity of their native climate has made the berries hardy, and both plant and fruit will stand extremes of heat and cold better than any other variety.

Price-10 cents each; 6 for 50 cents; 100 for $\$ 6.00$.

\section{Strawberry}

The ground should be worked 10 or 15 inches deep and be properly enriched as for any garden crop. Drainage is necessary in very wet soil.

For family use plant fifteen to eighteen inches apart each way, and after a few strong plants have been set from runners, then pinch off all runners as fast as they appear. Keep the ground free from weeds and frequently stirred with a hoe or fork. Plants treated in this manner will produce more crowns and therefore double the amount of well-developed fruit than when runners are left to grow.

When the winters are severe, it is well to give the ground a light covering with coarse straw or litter. The covering should not be placed on until the ground is 
frozen. Fatal errors are made by putting on too much and too early. If coarse straw is used, it may be left on until the plants have done fruiting, taking care to open it up around the plants early in the spring, so as to give them plenty of sunlight and air.

Price-1 cent each; 60 cents per $100 ; \$ 4.00$ per 1,000 .

Price in September and October $-\$ 1.00$ per $100 ; \$ 6.00$ per 1,000 .

Beder Wood. (Per.) - Ripens a week ahead of Crescent; gives heavy pickings from the start, and holds out until the rush of mid-season.

Senator Dunlap (Per.) - A well-tested, wonderfully productive variety, one of the safe sorts to plant everywhere and sure to take a high place among the prominent standard sorts. Plant resembles Warfield, rampant runner, should be restricted in its production of plants, fully equal to Crescent and Warfield in its ability to succeed under all circumstances. Fruit good size, regular form, beautiful bright red, glossy, firm, splendid keeper and shipper, excellent quality, one of the best for canning; ripens early and continues a long time. It promises to stand at the head in its wonderful ability to ripen a good crop under almost any condition of drought or neglect.

Crescent-Perhaps the most popular of all. Plants strong, hardy and very pro- ductive; fruit extremely large, dark red, fine flavor. A splendid market variety. Imperfect.

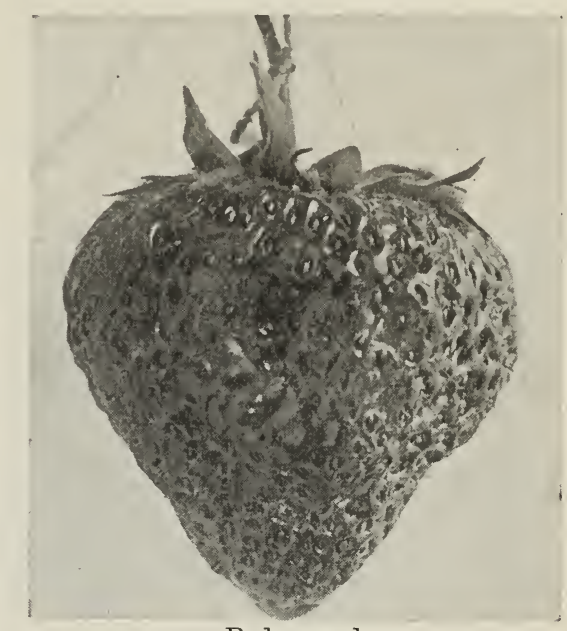

Bederwood.

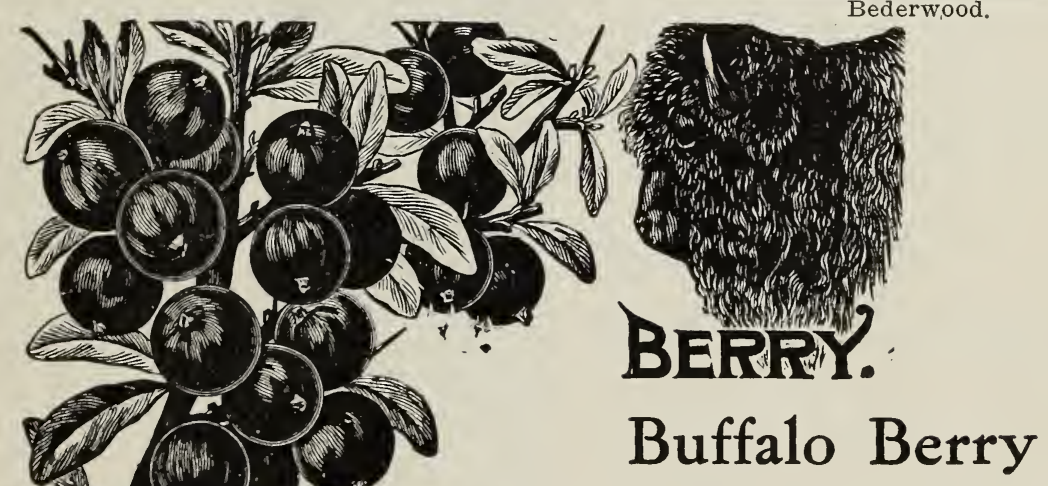

The Buffalo Berry belongs to the Olive family

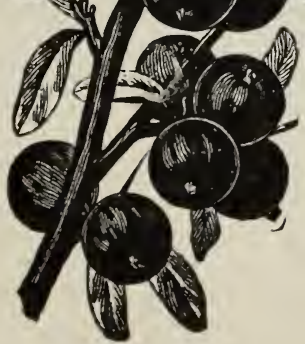

of trees. It grows in bush form and sometimes attains a height of ten feet; its leaves are of bright silvery color, and with its load of red fruit, makes a nice shrub. It is perfectly hardy, and bears immense crops of fruit, which is very good for tarts, jellies, pies and preserves.

It is sometimes called the winter currant from the fact that fruit remains on until January.

Price-2-foot trees, 20 cents each; 6 for $\$ 1.00$.

Price-Bearing size, 4 to 5 feet, 50 cents each; 6 for $\$ 2.50$. 


\section{Japanese Wineberry}

This is an entirely new, distinct and valuable berry. It belongs to the raspberry family; is a strong, vigorous grower, attaining the usual height of the raspberry, and is said to be perfectly hardy in all positions without protection. The leaves are of the darkest green on the outside and silvery white underneath. The young shoots or branches are covered with a reddish brown hair or moss. The fruit is borne in large clusters, often 70 to 100 berries in a bunch. These berries are, from the time of formation and bloom until they are ripe, enclosed in a "burr" which is caused by the calyx covering them entirely. When ripe the burr opens, exhibiting a large berry of the brightest, light glossy scarlet or cherry wine color. The burrs and stems are covered with a heavy reddish moss like a moss rose bud. The flavor of the fruit is entirely different from that of any other berry, being very sprightly, sweet and juicy, having no disagreeable sour, but a delicious and luscious flavor peculiar to itself, and superior to other berries. It commences to ripen early in July, and continues in bearing for a long time. It is the most prolific berry known, the bushes being literally covered with its luscious fruit. It is propagated from the tips like cap raspberries and dewberries, and can be increased rapidly.

Price-15 cents each; 12 plants for $\$ 1.00$.

\section{Asparagus}

To prepare bed for planting, the soil should be dug deeply, and well mixed together with well rotted manure or compost. Plant in rows two feet apart. In the rows the plants should not exceed a foot apart, and planted about four inches deep. Cover on approach of winter with manure, and fork the bed over lightly in the spring.

Price-10 cents per $10 ; 75$ cents per $100 ; \$ 6.00$ per 1,000 .

Conover's Colossal-A mammoth variety of vigorous growth, sending up from fifteen to twenty sprouts each year, from one to two inches in diameter; color deep green, and crown very close.

Palmetto-It is earlier, a better yielder, more even and regular in its growth and quality, equal to the old favorite, Conover's Colossal.

\section{Rhubarb or Pie Plant}

This deserves to be ranked among the best early vegetables in the garden. It affords the earliest material for pies and tarts, continues long in use, and is valuable for canning. Make the border very rich and deep.

Price-10 cents each; 60 cents per $10 ; \$ 4.00$ per 100 .

Linnaeus-Large, early, tender and fine; the very best of all.

Victoria-The best for market because of its giant growth.

\section{Horse Radish}

Price-3 cents each; 20 cents per $10 ; \$ 1.50$ per 100 .

\section{Elderberries}

A well-known bush which bears a fine fruit for pies or wine.

Price-15 cents each; 10 for $\$ 1.00$. 


\section{Ornamental Shrubs}

Althea or Rose of Sharon - These are fine shrubs and especially valuable because of their flowering in the fall when nearly all other shrubs are out of blossom. Hardy and easy of cultivation. 20 cents each.

Almond-Dwarf, double, rose-flowering. A beautiful shrub with small, double rosy blossom, closely set upon the twigs before the leaves appear. 20 cents each.

Japan Snowball-A rare and exceedingly beautiful species from Japan. Flowers pure white, in very large globular heads. 2-foot trees, 35 cents each.

Bechtel's Double-Flowering Crab-A medium-sized, hardy ornamental tree of great beauty. When in bloom this tree presents the appearance of being covered with roses, fragrant flowers of immense size, sure to give satisfaction to those who plant this beautiful tree. 3 to 4 -foot trees, 35 cents each.

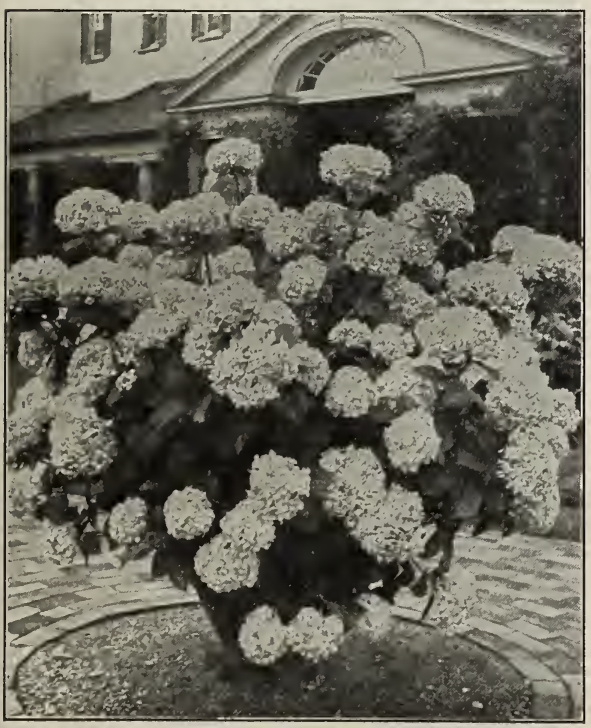

Hydrangea

Calycanthus-(Sweet Scented Shrub, or Allspice)-An interesting shrub, having a rare and peculiar fragrance of wood and flowers, its blooms are abundant and of peculiar chocolate color. 25 cents each.

Hydrangea-A fine shrub of recent in- troduction, blooming from July to November. Large, showy panicles of white flowers in the greatest profusion. It is quite hardy and altogether a most admirable shrub for planting singly on the lawn or in the margin of masses. To produce largest flowers it should be pruned severely in the spring and the ground enriched. 2foot plants, 25 cents each.

Tree Hydrangea -4 to 5 feet high, 50 cents each.

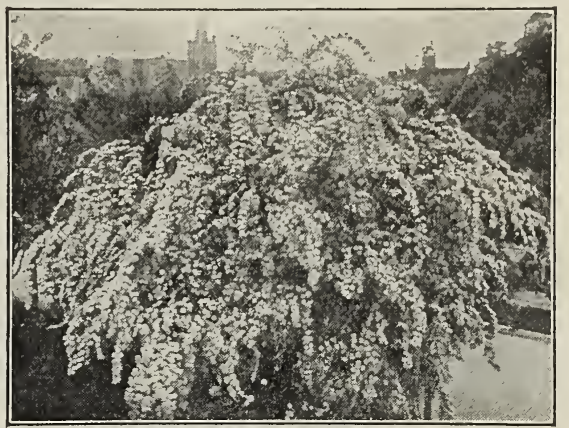

Spirea Van Houtte

Spirea-(Van Houttei)-The best White Spirea. The annual growth is long and abundant, and covered in June with a wealth of pure white blossoms. Perfectly hardy. Should be in every collection. 20 cents each.

Spirea - (Anthony Waterer) - A small dwarfish grower, 15 to 18 inches high, and is covered the entire season with large umbels of deep pink flowers. Quite hardy here and very desirable. 25 cents each.

Lilac, Persian Purple - A well-known shrub of glossy-green foliage and beautiful, fragrant flowers. A good plant for the lawn and one of the best for a fancy hedge. Hardy anywhere. Flowers purple. 20 cents each.

Lilac, Persian White-Same as above, with white flowers. 20 cents each.

Mock Orange, or Syringa-The Syringa is a large shrub, growing from 6 to 10 feet high. Vigorous habit, very hardy, with large, handsome foliage and beautiful white flowers. Very fragrant. Blooms very freely. Hardy. 20 cents each. 


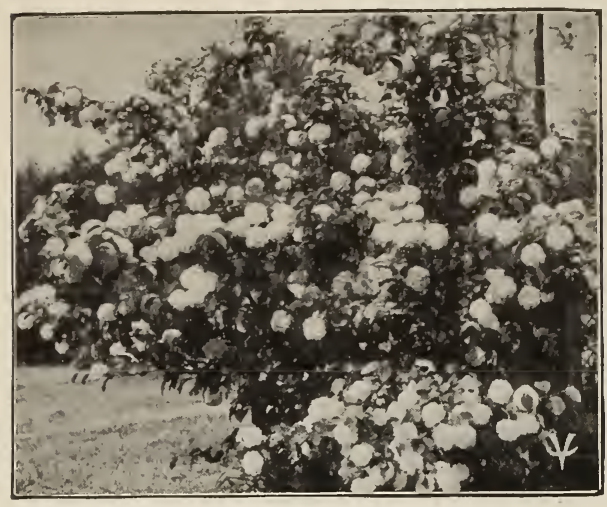

Snowball

Snow Ball-A well-known and favorite shrub of large size. Bears balls of pure white flowers in June. We have a bush on our farm on which we counted over 800 blossoms at one time. Hardy everywhere. 20 cents each.

Weigelia Rosea-Of Japanese origin, producing a mass of flowers from July until fall. Very ornamental, flowers dark rose with lighter center. Very hardy. 20 cents each.

Weigelia-(Eva Rathke)-Brilliant carmine in color, almost continuous bloomer; very fine. Price, 25 cents each.

\section{Climbing Vines}

Clematis Paniculata-(New Sweet Scented Japan Clematis)-No introduction of recent years has met with such ready sale and given so perfect satisfaction wherever planted. It grows and thrives anywhere and is a very rapid grower and profuse bloomer. The flowers are pure white. Its extreme hardiness, bright green foliage and delightfully fragrant flowers serve to make this one of the finest hardy climbing plants in cultivation. Strong, 2-year plants, 25 cents.

Clematis-(Jackmanii) - A very beautiful blooming variety, with flowers from four to six inches in diameter, of an intense violet purple color, borne successfully in continuous masses on the summer shoots. 35 cents each.

Henryi-Fine, large, creamy white flowers, strong grower and very hardy. One of the best of white varieties. A perpetual bloomer. 40 cents each.

Clematis - (Mad. Andre) - Red, very strong grower, producing large flowers. 35 cents each.

Honeysuckle - (Monthly Fragrant or Dutch) - Blooms all summer, very sweet. Red and yellow flowers. 20 cents each.

Bigonia, or Trumpet Flower-(Scarlet Radicans) - A splendid climber, vigorous and hardy, with clusters of large trumpet-shaped scarlet flowers in August. 20 cents each.

Virginia Creeper-A native vine of rapid growth, with large, luxuriant foliage, which in the autumn assumes the most gorgeous and magnificent coloring. The blossoms, which are inconspicuous, are succeeded by handsome dark blue ber-

ries. The vine is the best calculated to take the place in this country of the celebrated English Ivy, and is really in summer not inferior to it. $15 \mathrm{c}$ each.

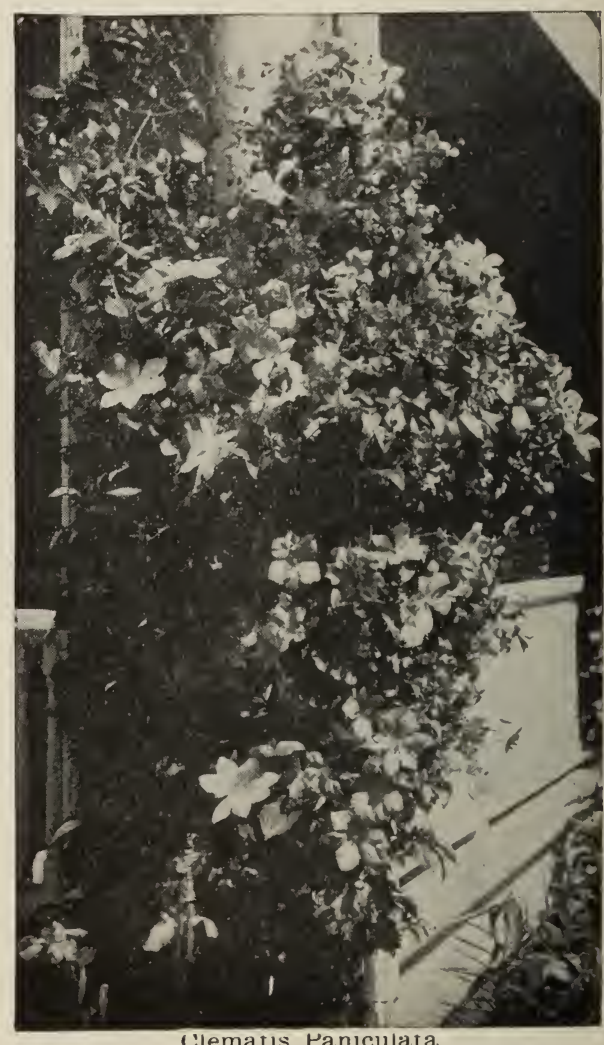


Wistaria-(Double Purple)-A rare and charming variety, with perfect double flowers, deeper in color than the single, and the racemes of remarkable length. The plant is perfectly hardy, resembling the single IVistaria, so well known as one of our best climbing plants. 20 cents each.

Boston Ivy-A beautiful hardy climbing plant. This is one of the finest climbers we have for covering walls, as it clings firmly to the smoothest surface, covering it smoothly with overlapping foliage, giving it the appearance of be- ing shingled with green leaves. The color is a fresh deep green in summer, changing to the brightest shade of crimson and yellow in autumn. It is quite hardy and becomes more popular every year. Strong plants, 25 cents each.

Hall's Japan Honeysuckle-This beautiful honeysuckle is almost evergreen, very strong and hardy in growth. The flowers are delightfully fragrant, and bloom profusely from May until frost; a handsome and valuable vine. 15 cents each.

\section{Roses}

Our roses are all very strong two-year-old plants, either grown on their own roots or budded on Manetti, and are not to be compared with the puny greenhouse roses from 2 -inch pots sent out by some nurserymen.

\section{Climbing Roses}

Crimson Rambler-The famous crimson clustered climber, so extremely effective when grown on pillars and trellises. The plant is a vigorous grower, making shoots 8 to 10 feet long in a season. The foliage is large and glossy, the plant looks like a mass of double crimson flowers when in bloom. The panicles are large and remain perfect for several weeks. Perfectly hardy anywhere. Price, 25 cents each.

Yellow Rambler - Flowers of medium size, in immense clusters, very sweet scented; a clear, decided yellow. The hardiest of all yellow climbing roses. It is a rampant grower, well established plants often making a growth of 10 to 12 feet in a season. 25 cents each.

White Rambler - Resembles Crinuson Rambler in. foliage and habit; flowers pure white. 25 cents each.

"Baby Rambler"-A dwarf (bush, not climbing) form of Crimson Rambler, and furthermore, ever-blooming. Will bloom continuously throughout the summer if planted out of doors. Has the same bright crimson color as the Climbing Rambler, and blooms in clusters of 20 to 40 flowers at one time on plants of fair size. "Baby Rambler" is one of the best red roses for bedding, and is going to be just as popular and as extensively planted as the climbing form has been. May be grown in pots. 2-year plants, 35 cents each.

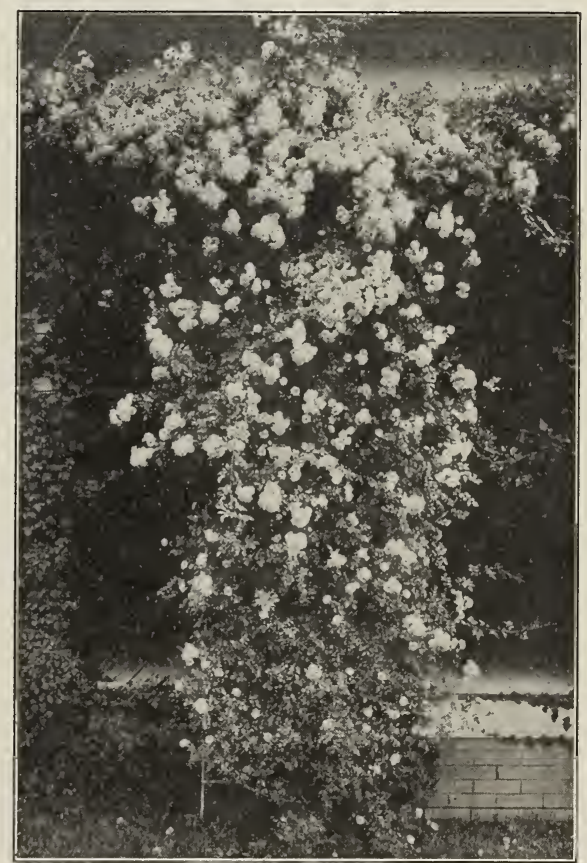

Crimson Rambler

Baltimore Belle-Pale blush, is almost white; very double and fragrant. 20 cents each.

Greenville, or Seven Sisters - P u r p 1 e crimson and pink, not quite hardy. 20 cents' each. 
Queen of the Prairie-Bright rose color; large and double; very vigorous and rapid in its growth; the best climbing rose. 20 cents each.

\section{A Blue Rose}

The Greatest Rose Novelty of the Century

The New Rambler-(Violet Blue) hailed by the German rose growers as the forerunner of a genuinely cornflower blue rose, is a seedling of Crimson Rambler, very vigorous and hardy and free blooming. 50 cents each.

\section{New Ever-Blooming Crim- son Rambler Rose}

A sort of the well-known and famous Crimson Rambler climbing rose. This new rose produces its lovely flowers until killing frost stops further growth of the plant. The flowers are produced in great trusses, each carrying from thirty to forty blooms of the brightest crimson, which remains undimmed to the end. Combined with the waxy, pale green, red veined foliage, the glowing crimson mass of bloom makes an irresistible effect. The new Everblooming Crimson Rambler produces its flowers on the ends of new shoots, and if cut as soon as faded, many new side branches will form which soon are covered again with a great mass of blossoms. By blooming so constantly, the new shoots are not as large as with the old Crimson Rambler, but the wood is more firm and less subject to mildew, another point in its favor. The plant is exceeding hardy, having successfully withstood the test in exposed situations of very severe winters. A magnificent everblooming rose for covering trellises, walls, porches, etc., as they succeed under any circumstances and bloom wonderfully profuse throughout the summer. It is one of the finest and best novelties of recent introduction and will be very popular.

Price-2-year-old, field-grown plants, 50 cents each.

\section{Memorial Rose}

A rose of trailing habit, a very hardy and rapid grower, with a glossy foliage, which remains on until late in the fall. Its flowers are pure white and very fragrant. It is especially adapted to cemetery planting, hence its name; or it may be trained as a screen to hide some unsightly root, stump or rock. 20 cents each.

\section{Monthly Blooming Roses}

Marshall P. Wilder-Color bright cherry carmine, fragrant, of vigorous growth, with fine foliage, one of the freest of the hybrid perpetuals to bloom. We can recommend this rose without hesitation. 25 cents each, five for $\$ 1.00$.

Paul Neyron-Deep rose color, splendid foliage and habit, with large flower. 25 cents each, five for $\$ 1.00$.

Ulrich Brunner-The flowers are very large, of beautiful form and very double; color, deep, rich rose. 25 cents each, five for $\$ 1.00$.

Anne de Diesbach-Carmine, beautiful shade moderately full and very large. 25 cents each, five for $\$ 1.00$.

Madame Plantier-One of the finest pure white roses, blooming in clusters. 20 cents each, six for $\$ 1.00$.

Persian Yellow-Deep golden yellow; double and very fine. 30 cents each.

Coquettes des Blanches-Pure white, flowering in clusters, very free bloomer. 25 cents each, five for $\$ 1.00$.

General Washington - Brilliant rose crimson, large, double, fine. 20 cents each, five for $\$ 1.00$.

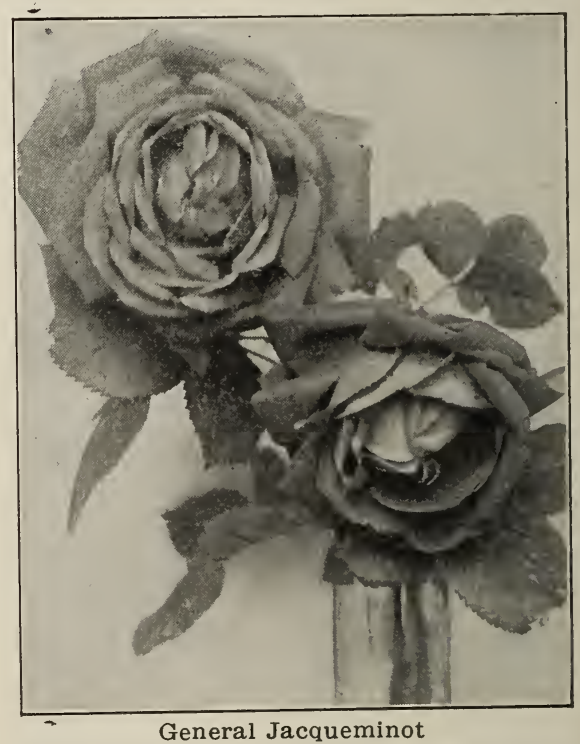

General Jacqueminot - Brilliant crimson scarlet, very showy and effective. 20 cents each; five for $\$ 1.00$. 
Madam Chas. Wood-One of the most beautiful hybrid perpetual roses ever introduced. The flower is extra large, full and double, color deep rose crimson, sometimes brilliant scarlet with maroon shading, it blooms soon after planting out and continues to bloom all summer. 20 cents each, five for $\$ 1.00$.

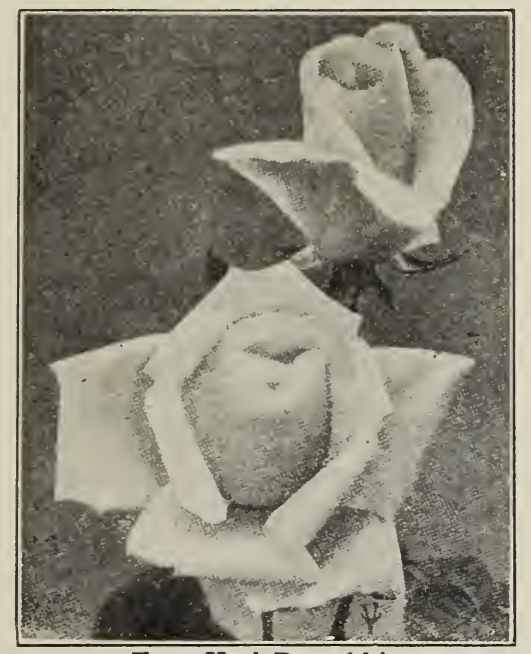

Frau Karl Druschki

American Beauty-One of the best and most valuable roses, both for garden and house culture. Color rosy crimson, exquisitely shaded and very handsome. Extra large full flowers and fine buds. The plant is very hardy and a constant bloomer. Each shoot produces a bud. The fragrance is delightful. Vigorous growth and has the everblooming qualities of the Tea Rose. Each, 35 cents.

Frau Karl Druschki-Or White American Beauty-A pure paper white, free flowering, large size Hybrid Perpetual. It is a remarkably handsome plant with bright, heavy foliage and strong, upright growth. The bloom is perfect in form on fine, long stems, and of the the purest possible white. There is nothing in the line of perfectly hardy roses that can compare with this one in form, color and general finish. 2year field grown, 35 cents each.

\section{Moss Roses}

The Moss Rose is as hardy as any rose can be, and an extra vigorous grower. They are much admired on account of their bright, healthy foliage and mossylike covering of the buds. While they bloom but once a year, the flowers are large, beautiful and plentiful.

Capt. John Ingram-Dark, velvety purple, full and fine. 25 cents.

Glory of Mosses-Pale rose, very large, full and beautiful. 25 cents each.

Perpetual White-Pure white. It blooms in large clusters. 25 cents each.

\section{Tree Roses}

These are grafted on hardy rose stalks 4 to 5 feet high, are tree shaped and when in full bloom are objects of beauty, making handsome plants for the lawn, or as border plants along the sidewalk or driveway. They are coming into popular favor and at the low price we are offering them this year anyone can set out a few of these pretty tree roses in his yard or on the lawn.

Crimson Rambler Tree Rose-No other rose is so well adapted for growing in tree form. The branches droop gracefully and reach nearly down to the ground, thus forming a regular weeping tree. 75 cents each.

Hybrid Perpetual Tree Rose - These hardy and free blooming roses we have in tree form and can furnish the following colors: Red, White and Yellow. 75 cents each; 10 for $\$ 6.50$.

Baby Rambler Tree Rose-A most attractive novelty in hardy roses. Budded on strong, straight stems four feet high; the round, bushy, Baby Rambler tops at all times a perfect mass of crimson bloom. The most florescent and striking of all tree roses. $\$ 1.00$ each. 


\section{Russian Mulberry}

This tree has been planted very extensively in the Western States for the past fifteen years, and we know of no other tree that will stand as much drought and neglect and yet make a good growth each year.

It makes a very good shade tree, holding its leaves late into the fall; and for a hedge, without thorns, it has no superior.

Trees commence to bear at two years old; fruit resembles the blackberry, and will ripen from July 1st to September. Per 1 Per 10 Per 100 Per 1,000 5 to 6 feet, well branched, transplanted......\$0.15 $\$ 1.25 \quad \$ 10.00 \quad \$ \ldots$ 4 to 5 feet, well branched, transplanted....... .08

3 to 4 feet, well branched, transplanted......... .07

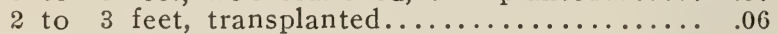

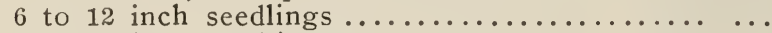

12 to 18 inch seedlings $\ldots \ldots \ldots \ldots \ldots \ldots \ldots \ldots \ldots \ldots \ldots \ldots \ldots \ldots$

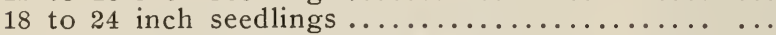

Downing Everbearing, 3 to 4 feet.................

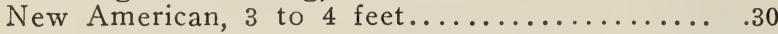

$\begin{array}{rrr}.70 & 6.00 & \ldots \\ .60 & 5.00 & \ldots \\ .50 & 4.00 & \ldots . \\ \ldots . & .25 & 2.00 \\ \ldots . & .35 & 3.00 \\ \ldots . & .70 & 6.00 \\ 2.50 & \ldots . & \ldots . \\ 2.50 & \ldots . & \ldots .\end{array}$

\section{Weeping Trees}

These trees form objects of great beauty when planted as single specimens on lawns, in the front yard and especially when used for cemetery decorations. Also of great value for covering arbors. Our list embraces the best varieties.

Tea's Weeping Mulberry-We cordially recommend this as one of the thriftiest, hardiest and most beautiful of weeping trees. It transplants easily and is appropriate for both large and small places. The leaves are lustrous, distinctly lobed; the branches slender

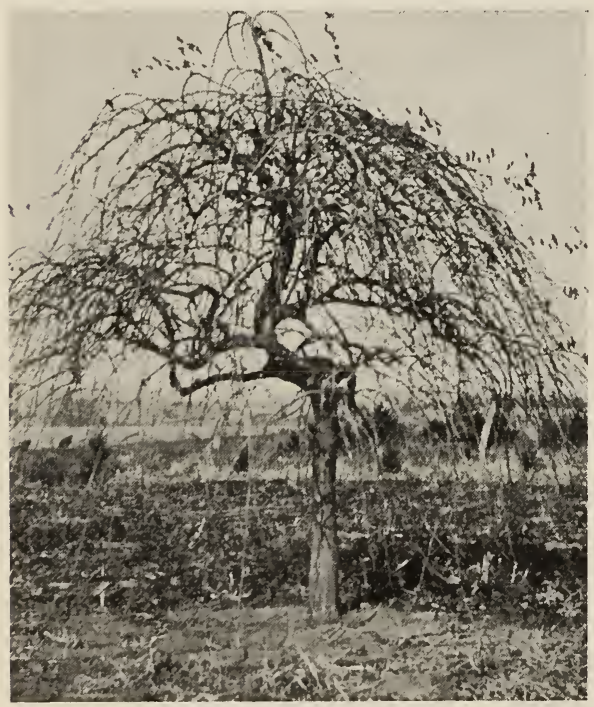

Tea's Weeping Mulberry and willowy, forming a tall, narrow green tent of dense shade. Fine trees $\$ 1.00$ each.

Catalpa Bungeii or Umbrella Tree-One of the finest ornamental trees we have; it is perfectly hardy; you will be pleased with this tree on your lawn. Trees grafted, 7 feet high, 75 cents each.

Weeping Birch - Cut leaved. Probably the most popular and desirable lawn tree in existence, and produces a beautiful effect on streets and avenues. Makes a vigorous growth and is perfectly hardy. Trunk straight, slender, white as snow; the slim side branches dooping in a most picturesque manner; foliage delicate and deep cut, coloring finely in the fall. The drooping branches and silvery bark form a most effective combination during the winter months. 75 cents each.

Camperdown Weeping Elm-Its vigorous branches, which have a uniform habit, overlap so regularly that a compact roof-like head is formed. Leaves are large, glossy dark green. A strong, vigorous grower. One of the best weeping trees. It can be trained to form an arbor if desired. The peculiar characteristics of this tree make it very popular and valuable for the lawn. Hardy. $\$ 1.00$ each.

Per 1

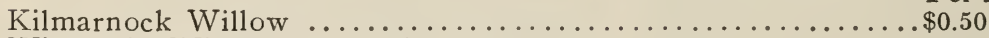

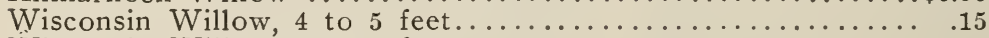

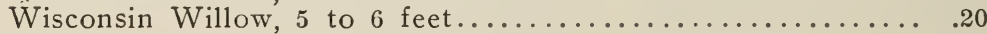

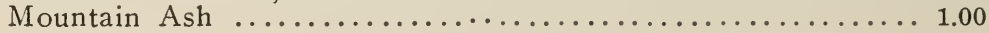

Per 10 $\$ 4.50$ 1.00 1.50 


\section{Shade Trees}

Ash, Soft Maple, Box Elder, Black Locust and Caro-

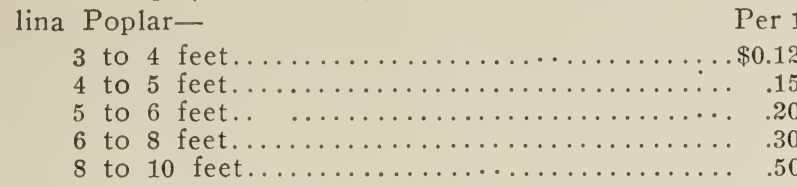

$\begin{array}{rr}\text { Per } 10 & \text { Per } 100 \\ \$ 1.00 & \$ 8.00 \\ 1.20 & 10.00 \\ 1.50 & 12.00 \\ 3.00 & 25.00 \\ 4.50 & 40.00\end{array}$

Elm and Sycamore-

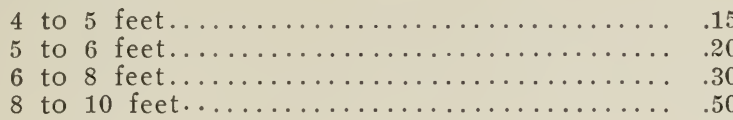

$\begin{array}{ll}1.30 & 12.00\end{array}$

$1.75 \quad 15.00$

$2.50 \quad 20.00$

$4.75 \quad 45.00$

Mountain Ash, 4 to 5 feet........................ $25 \quad 2.00$

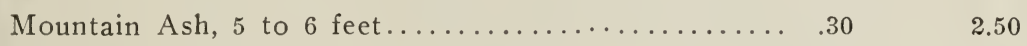

Hard Maple, 5 to 6 feet.......................... 35

Hard Maple, 6 to 8 feet................. .50 4.00

Horse Chestnut, 5 to 6 feet..................... .50 4.00

Russian Olive, 4 to 5 feet......................... $40 \quad 3.50$

White Birch, 4 to 5 feet................... .20 1.50

White Birch, 5 to 6 feet....................... $25 \quad 2.00$

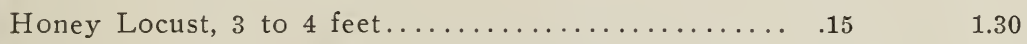

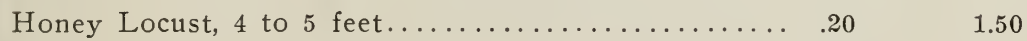

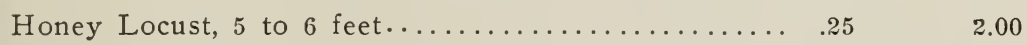

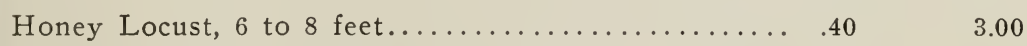

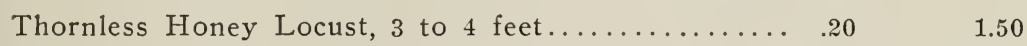

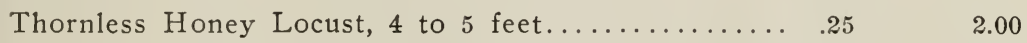

Thornless Honey Locust, 5 to 6 feet................. $35 \quad 3.00$

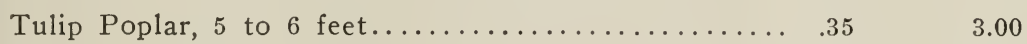

American Linden, 5 to 6 feet.................... $35 \quad 3.00$

American Linden, 4 to 5 feet..................... $25 \quad 2.00$

\section{Cuttings}

Cottonwood and Carolina Poplar.

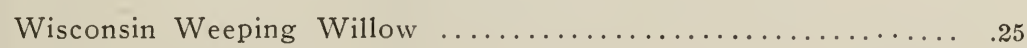

$\$ 1.50$

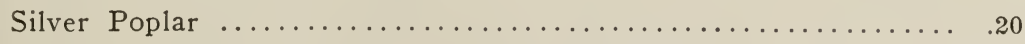

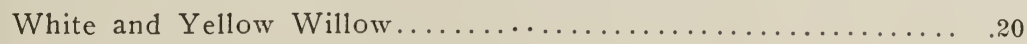

Concord Grape 


\section{Forest Tree Seedlings}

We have millions of them, principally Black and Honey Locust, Catalpa and Mulberry. Lumber and posts are becoming more expensive every year, and people could save a great deal of this expense by planting some of the quick-growing forest trees. Nearly every farm has some waste land that could be used for this purpose.

Ash, 6 to 10 inches............................ Per 10

Ash, 10 to 15 inches........................................

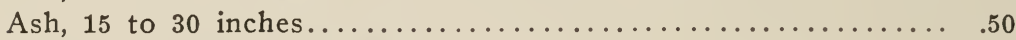

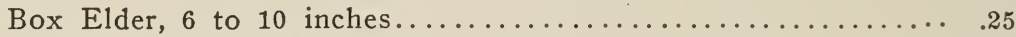

Box Elder, 10 to 15 inches.............................35

Box Elder, 15 to 20 inches...........................50

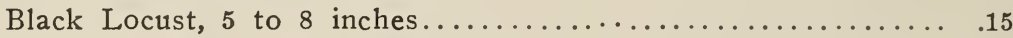

Black Locust, 8 to 12 inches........................ .20

Black Locust, 12 to 18 inches...........................25

Black Locust, 18 to 24 inches......................... .40

Honey Locust, 6 to 12 inches........................ .20

Honey Locust, 12 to 18 inches......................... .30

Honey Locust, 18 to 24 inches........................ .50

Thornless Honey Locust, 6 to 12 inches................. .35

Thornless Honey Locust, 12 to 18 inches...................45

Thornless Honey Locust, 18 to 24 inches.................. .60

Soft Maple, 18 to 24 inches........................... .60

Soft Maple, 24 to 36 inches........................... 1.00

Sugar Maple, 12 to 18 inches........................... 65

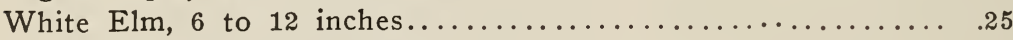

White Elm, 12 to 18 inches..............................45

Catalpa Speciosa, 6 to 12 inches........................ .30

Catalpa Speciosa, 12 to 18 inches........................40

Cottonwood, 10 to 15 inches........................... 20

American Linden, 12 to 18 inches..................... 4.00

Sycamore, 12 to 18 inches............................. 2.00

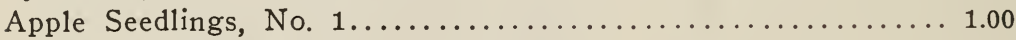

Apple Seedlings, No. $2 \ldots \ldots \ldots \ldots \ldots \ldots \ldots \ldots \ldots \ldots \ldots \ldots \ldots \ldots . . .70$

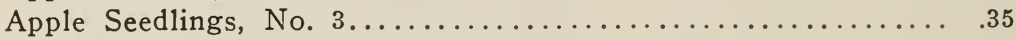

Per 1,000

$\$ 2.00$

3.00

4.50

2.00

3.00

4.00

1.15

1.40

2.25

3.50

1.50

2.50

4.00

3.00

4.00

5.00

5.00

8.00

5.00

2.00

4.00

2.50

3.50

1.50

15.00

8.00

5.00

3.00

\section{Hedge Plants}

\begin{tabular}{|c|c|c|}
\hline Per 10 & Per 100 & Per 1,000 \\
\hline Privet, 6 to 12 inches........ & $\$ 1.75$ & $\$ 15.00$ \\
\hline Privet, 12 to 18 inches.. & 2.50 & 20.00 \\
\hline Privet, 18 to 24 inches..................... 40 & 3.00 & 25.00 \\
\hline 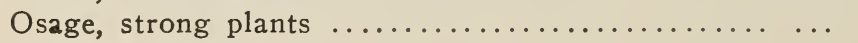 & .35 & 3.00 \\
\hline Osage, good plants $\ldots \ldots \ldots \ldots \ldots \ldots$ & .25 & 2.00 \\
\hline Russian Mulberry, 6 to 12 inches............... & .25 & 2.00 \\
\hline 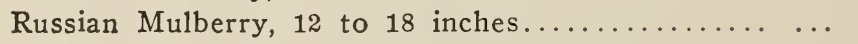 & .35 & 3.00 \\
\hline Russian Mulberry, 18 to 24 inches............. & .70 & 6.00 \\
\hline
\end{tabular}




\section{Seeds}

Per oz. Perlb.

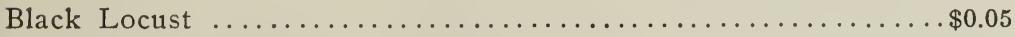

$\$ 0.40$

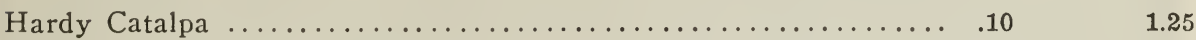

Honey Locust ................................... .05

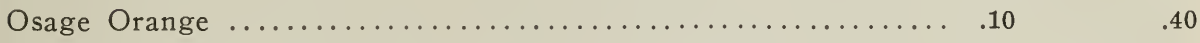

Russian Mulberry .................................. .20 3.00

If you want seeds sent by mail, add 8 cents per pound to price.

\section{Apple Grafts}

Send in your orders for grafts early. The first of March we commence to plant and after that date our list of varieties is broken.

Per 100 Per 1,000

No. 1 Piece Root ...........................\$1.00

$\$ 7.00$

No. 1 Whole Root

2.00

14.00

\section{Nut Trees}

\begin{tabular}{|c|c|c|c|c|}
\hline & Per 1 & Per 10 & Per 100 & Per 1,000 \\
\hline Sweet Chestnut, 5 to 6 feet............. & . $\$ 0.35$ & $\$ 3.00$ & $\ldots \ldots$ & $\ldots$. \\
\hline 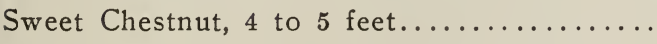 & . . .30 & 2.50 & $\ldots \ldots$ & $\ldots$. \\
\hline English Walnut, 10 to 15 inches...... & . . .15 & 1.25 & $\ldots \ldots$ & $\ldots$. \\
\hline utternut, 6 to 12 inches......... & .03 & .20 & $\ldots \ldots$ & $\ldots \ldots$ \\
\hline utternut, 12 to 18 inches.... & .05 & .40 & $\ldots \ldots$ & . \\
\hline utternut, transplanted, 18 inches........ & .10 & .80 & $\cdots \cdots$ & $\cdots$ \\
\hline ack Walnut, 6 to 12 inches. & $\cdots$ & $\cdots$ & .60 & 5.00 \\
\hline ack Walnut, 12 to 18 inches. & $\ldots$ & $\ldots$ & .80 & 7.00 \\
\hline
\end{tabular}

\section{Sudden Sawlog}

Or Norway Poplar-A very promising tree but lately introduced and received its name from its very rapid growth. It resembles the Carolina Poplar, but makes a larger growth, both in height and thickness of limb.

Price-4-foot tree, 20 cents; 5 -foot, 25 cents; 6 -foot, 30 cents; 7 -foot, 35 cents; 8 -foot, 40 cents, and 10-foot, 50 cents each. Cuttings, 25 cents per $10, \$ 2.00$ per 100 . 


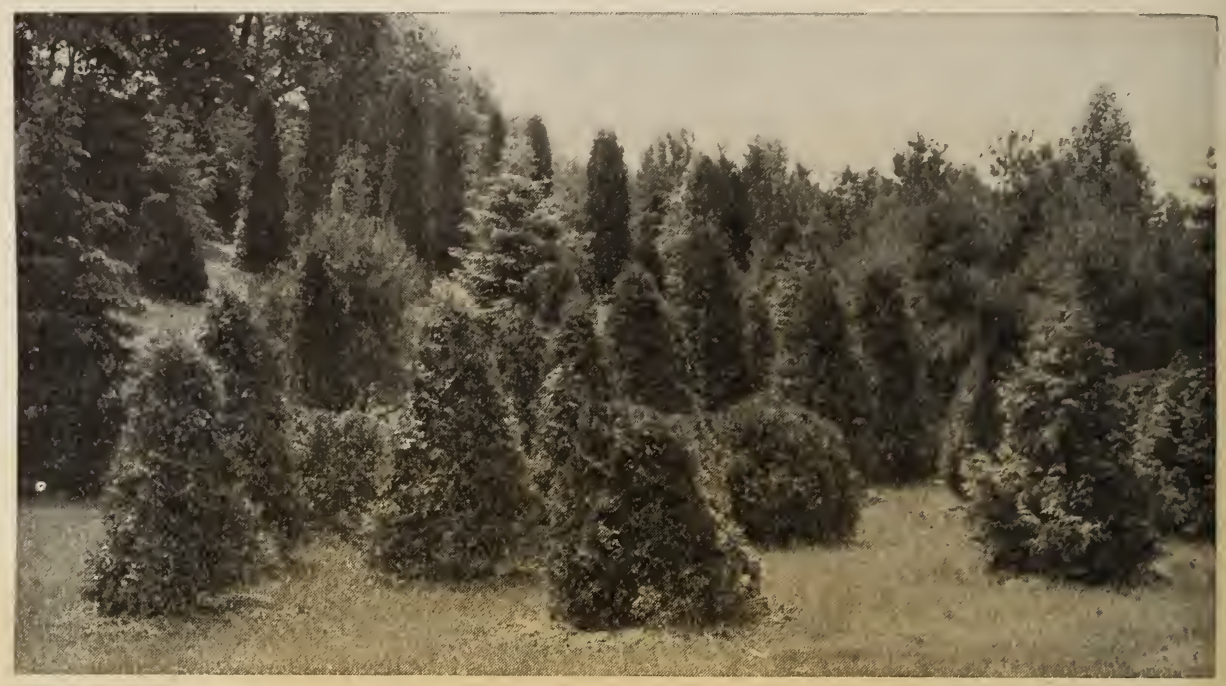

\section{Evergreens--Transplanted}

Scotch and Austrian Pine, 2 to 3 feet................. $\$ 0.35$

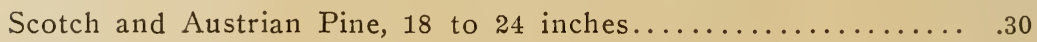

Per 10

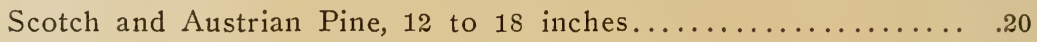

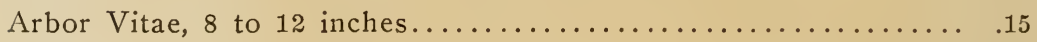

$\$ 2.50$

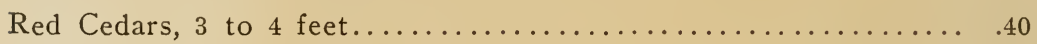

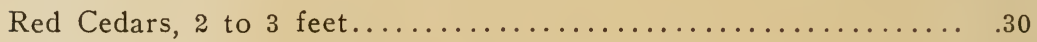

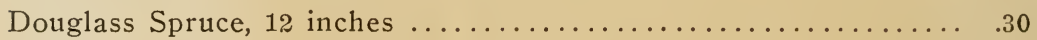

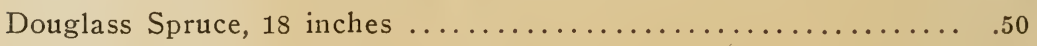

Blue Spruce, taken up with earth, select color, grafted, 24 inches.. 2.50

Blue Spruce, taken up with earth, select color, grafted, 12 inches.. 1.25

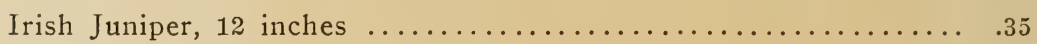

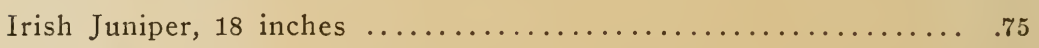

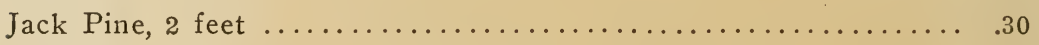

$\ldots .$.

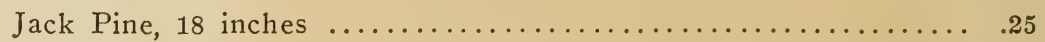

\section{Evergreen Seedlings}

Below we give prices on seedlings such as we use for our own plantings; they require a great deal of care for the first year after transplanting, but when once started will soon make fine trees.

Seedling evergreens are grown in the North and cannot be shipped until after April 15.
Scotch and Austrian

Per Per Per

$10100 \quad 1000$

Pines, 10 to 12 in.. $\$ 0.35 \$ 3.00 \quad \$ 20.00$

White Pine and Ar-

bor Vitae, 8 to 10 in $\quad .45 \quad 4.00 \quad 30.00$

Norway and White

Spruce, 10 to 12 in. $\quad .35 \quad 3.00 \quad 20.00$

Jack Pine, 10 to 12 in. $.35 \quad 3.00 \quad 18.00$ 


\section{Plant Department}

Greenhouse plants should not be shipped by freight. We pack well and ship by express, and customer pays the express.

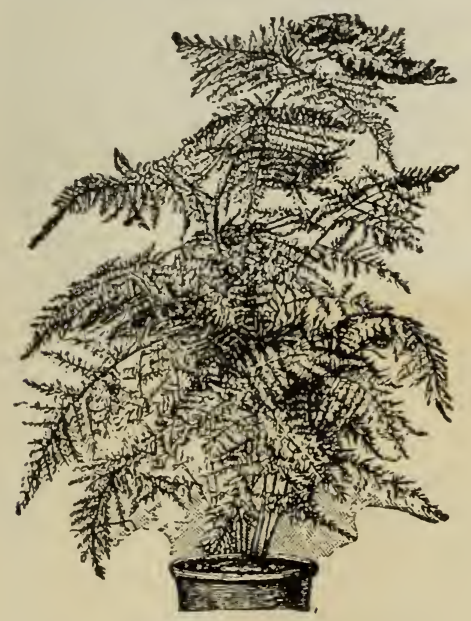

Asparagus Fern

Asparagus Plumosus or Asparagus Fern - It is a most elegant plant with smooth stems and has very graceful, arching, filmy foliage; it rivals the delicate beauty of the Maiden Hair Fern. The cut sprays of this variety endure for a long time. It is indispensable as a green in floral decorations. Remarkably fine for pot culture, as it is very ornamental. By mail 10 cents each, by express, large plants, 20 cents and up.

Asparagus Sprengeri-One of the best known plants introduced in years. This plant is exceedingly useful and ornamental as a pot plant. In a hanging basket it droops gracefully with branches that are sometimes 4 to 5 feet in length; of a rich shade of green. The fronds retain their freshness for weeks after being cut. Especially useful for planting in ferneries or in suspended baskets. It is fine for house decorations as it withstands dry atmosphere. By mail, 10 cents each; by express, large plants, 20 cents and up.

Rex Begonias-Well known as very decorative plants for the house. They do not require sun or even strong light and so can be used where other flowers or plants will not thrive. They should be given a nice, shady situation, and then soil should be light and porous, composed of rich loam, sand and leaf mold. The Rex varieties are very effective as pot plants. Care should be taken to keep the foliage free from dust. Occasionaily the plants may be showered, but should not be exposed to the sun un. til the leaves are perfectly dry. We have five of the best varieties. 20 cents each; larger plants by express from 25 cents up.

Caladium Esculentum-(Elephant's Ear) -For obtaining tropical effects in lawns and garden planting this beautiful plant takes a prominent place. Should have plenty of water and good rich soil. When at its best, stands six to seven feet high, with bright green leaves three to four feet long and two and one-half feet wide. Large bulbs 20 cents each, six for $\$ 1.00$.

\section{Callas}

One of the most satisfactory summer flowering bulbs when planted in open ground, and equally good as a pot plant for winter blooming, when planted in the fall, the foliage is a dark green, flowers pure white. Large bulbs 20 cents each; six for $\$ 1.00$.

\section{Cannas}

One of the most popular of bedding plants with their green and bronze foliage and bright flowers; we grow six of the best varieties. 10 cents each; one dozen $\$ 1.00$, for dry bulbs. Bulbs which have been started to grow in the greenhouse, 15 cents each; eight for $\$ 1.00$.

King Humbert -4 to 5 feet. Giant flowered, orange scarlet, bronze leaf. The flowers are very large and very free blooming. The handsome leathery foliage is of strong habit.

Florence Vaughn-5 feet. Green foliage; flowers are a rich golden yellow, thickly dotted brightest red.

Mad. Crozy-3 $1 / 2$ feet. Green foliage. Flowers vermillion with gold border.

Crimson Bedder-Bright crimson scarlet.

Shenandoah-5 feet. Bronze foliage, pink flowers. 
Pillar of Fire-6 feet. Green foliage, red flowers.

Mephisto - 4 feet. Green foliage, darkest red Canna grown.

\section{Carnations}

The Carnation is the most popular flower grown by florists, as they are much desired for house decoration and personal adornment. The new mammoth varieties are especially attractive. They are beautiful in coloring, perfect

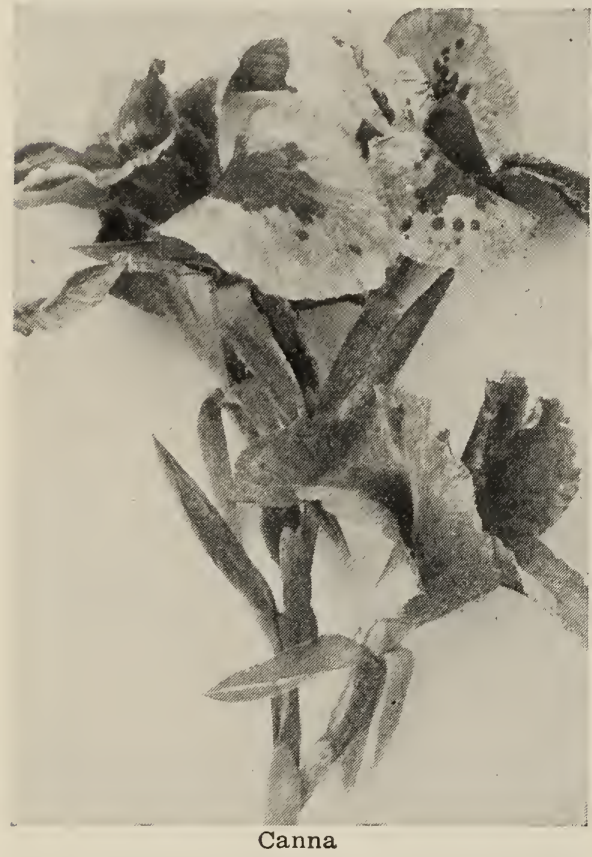

in form and shape, and some of them three and one-half inches across. We grow the following varieties as best for house culture. Plant in open ground in May. 15 cents each; six for 50 cents. Large plants by express in September and October for winter blooming, 25 cents each; five for $\$ 1.00$.

We can furnish them in the following colors: Red, light and dark pink, and white.

\section{Chrysanthemums}

We grow ten of the best varieties of yellow, white and pink "Mums." Plant in open ground in May. 10 cents each;

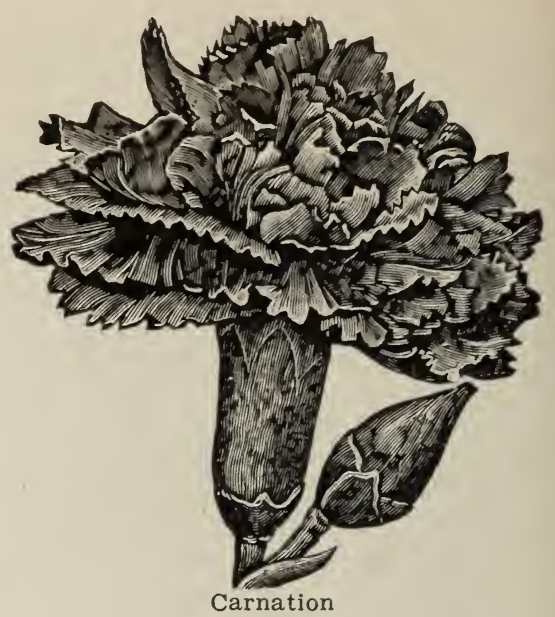

$\$ 1.00$ per dozen. Large plants in September and October, by express, 50 cents each.

\section{Coleus}

There is nothing in the line of bedding plants that can ever take the place of Coleus. Used in solid clumps or as edging to Canna beds, etc. We grow eleven of the best colored varieties; plant as soon as danger of frost is over. 5 cents each; 50 cents per dozen.

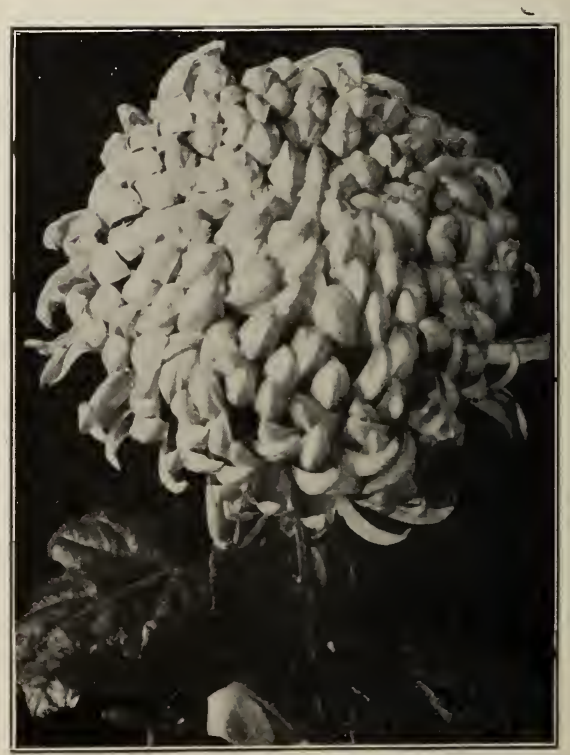

Chrysanthemum 


\section{Dahlias}

No garden is complete without a show of these brilliant and stately autumn flowers, and nothing gives greater return for so little money and care. We have a fine assortment of the best varieties of yellow, pink, red, white and maroon. Bulbs are too heavy to send by mail; express, 20 cents each; six for $\$ 1.00$.

\section{Fuchsias}

For window pot plants or for partially shady spots in the garden, these plants, with their gracefully drooping flowers, are held in high favor. We grow six varieties, 15 cents each; four for 50 cents.

\section{Ferns}

There are no more attractive plants, or plants that are more generally useful than Ferns. Their great beauty and diversity, together with their adaptability in arrangement with all kinds of flowering and ornamental plants. make them an almost indispensable adjunct to the home and conservatory. Not requiring strong light, they can be used to advantage in places the sun does not reach. Largely used also for cutting. as a few sprays serve to lighten and give an artistic finish to any bouquet or design. We list the most desirable varieties.

Whitman Fern-Similar to the Boston Fern only that the fronds are shorter and fringed. Prices same as Boston.

Boston - Sometimes called "Fountain Fern" on account of its gracefully drooping habit. Fully matured fronds often attain a length of four feet. 10c each.

\section{Large Plants by Express}

Each

3 -inch pot plants .........\$0.20

4 -inch pot plants $\ldots \ldots \ldots \ldots \ldots \ldots . . .6 \%$

5 -inch pot plants ...............60

6 -inch pot plants ............ 1.00

8 -inch pot plants ........... 1.50

10 -inch pot plants ........... 3.00

\section{Geraniums}

Throughout all the fluctuations of taste and requirements which popularize one class of plants and then another, Geraniums have held and still retain a foremost place in popular esteem, which seems impregnable. As pot plants they are always serviceable and useful; while for summer bedding purposes they are almost indispensable.

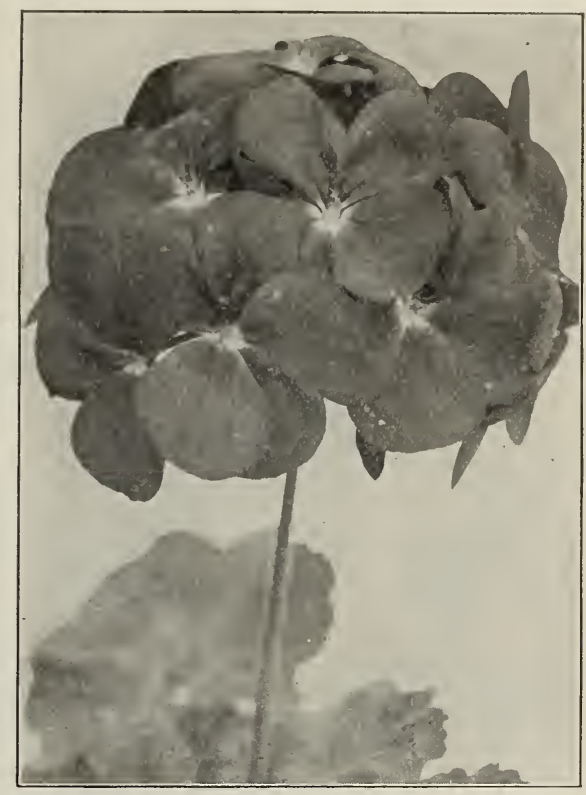

Geranium

\section{DOUBLE FLOWERING VARIETIES}

Unless otherwise noted, price $10 \mathrm{c}$ each; $\$ 1.00$ per dozen, postpaid. Geraniums in 4 -inch pots for bedding out in May and June, per dozen, $\$ 1.75$; per hundred, $\$ 12.00$ by express at customer's expense.

Beauty Poitevine - One of the semidouble and has no equal in its color; trusses immense and of a fine shape; color beautiful rosy salmon, nicely shaded and tinted. Foliage thick, leathery; strong habit of growth.

Jean Viaud-A wonderful fine Geranium for winter or summer blooming. Flowers semi-double, of largest size, borne on immense stalks. Color fresh bright rose pink, the upper petals marked with white blotches, adding greatly to freshness of coloring; grand everbloomer, fine form.

La Favorite-Trusses very large; purest snow white, even when grown in the open ground. 
Mrs. E. G. Hill-Large single flowers; bright salmon, with a light shading at center.

S. A. Nutt-Rich crimson. The old standby.

Alphonse Ricard $\longrightarrow$ Semi-double, dwarf and branching, bright orange red.
Mad. Salleroi-A very compact variety of Silver Geranium; very fine for massing or bordering, thrifty, healthy grower, rarely reaching a height of more than six inches; leaves very small, of peculiar clear green, edged with pure white.

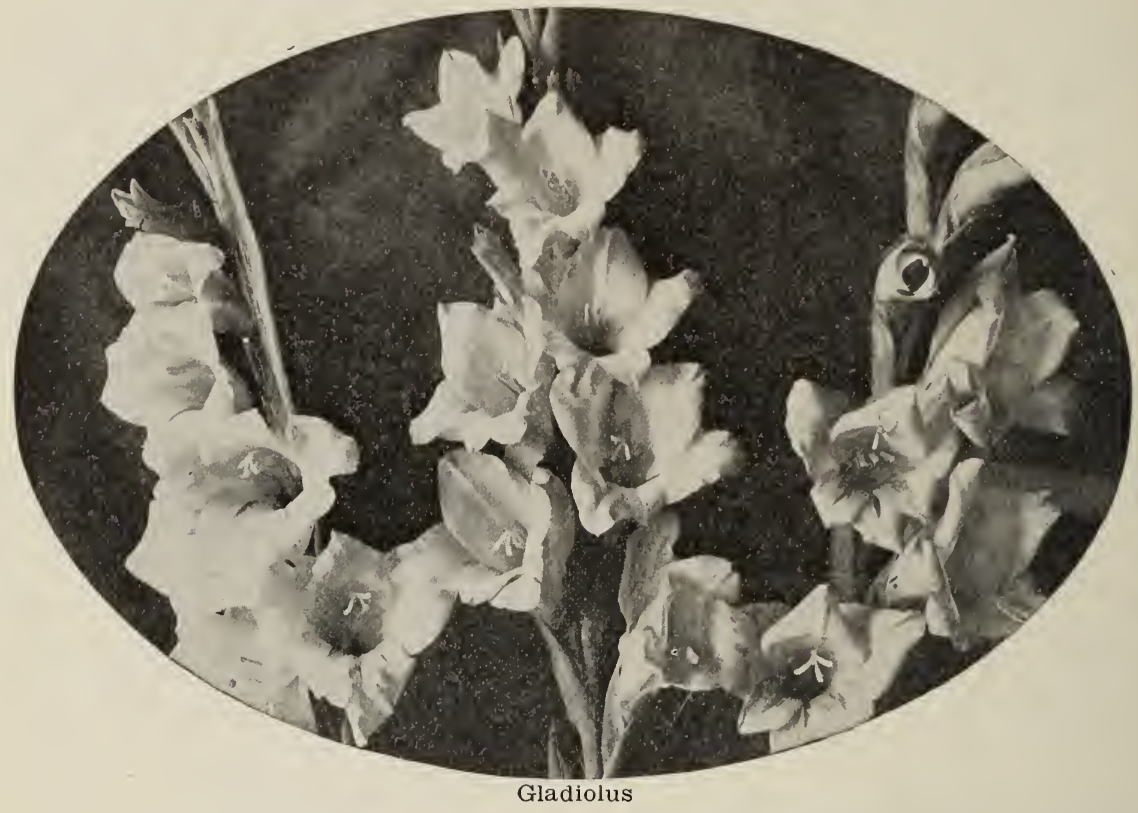

\section{Gladiolus}

One of the most attractive of summer flowering bulbs. Very ornamental for the lawn. To obtain a succession of bloom there should be several plantings made at intervals of a week. Set bulbs six to nine inches apart and about four inches deep. If the soil is poor see that it is carefully enriched. The flowers are excellent for cutting and last a week in water, the bulbs opening well. The bulbs should be taken up in the fall before heavy freezing weather sets in and allowed to dry off in the sun. Cut off the stem close to the bulb, put in paper bags and place where they will not freeze. A cold, dry atmosphere is best. We have a fine collection of the large flowering sorts. Dry bulbs, 5 cents each; $\$ 3.50$ per 100 .

\section{Heliotropes}

Florence Nightingale - Bright lavender, still one of the best and most popular. 10 cents each; six for 50 cents.

\section{Oleanders}

An old favorite, largely used for house, porch or lawn decorations. Easily wintered in a cellar where it does not freeze.

Pink and White-Double flowered. 20 cents each.

\section{Petunias}

Very easily grown and truly satisfactory wherever placed.

Purity - A remarkable fine, double Tower. Plant is strong and stocky; flowers are very large and very double, also finely fringed. Color, pure white.

Double Pink. Double Crimson-10 cents each; eight for 50 cents.

\section{Salvia or Scarlet Sage}

Splendens-A remarkably fine bedding plant. The latter part of summer and early fall it is covered with great 
masses of dazzling scarlet flowers, which remain in bloom until cut down by frost. 10 cents each; three for 25 cents.

\section{Smilax}

A very graceful climber, possessing the rare qualities of delicate and dense foliage and vining habit, admirably adapting it to climbing or drooping. It is fine as a parlor or window plant. 10 cents each.

\section{Moon Vine}

One of the most rapid growing vines, often forty feet in a single season, fine for trellises or screens, large white bloom. 10 cents each.

\section{Vinca Major Variegata}

More of this used for baskets and vases than there is of any other two basket plants. Beautifully variegated green and white foliage, and strong trailing habit of growth. 15 cents each; ten for $\$ 1.00$.

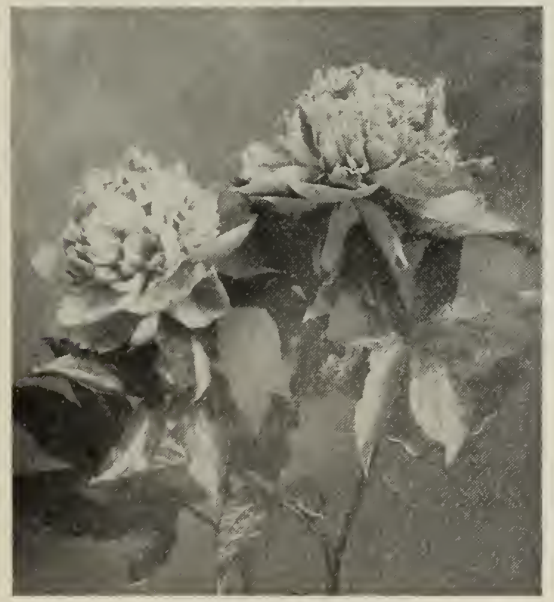

Japanese Peony

\section{Tuberoses}

Excelsior Pearl - Double white, dwarf, seldom over 18 inches high. 5 cents each; six for 25 cents.

Fall Double-Grows very large, often 5 feet; pure white double; blooms late in the fall. 5 cents each; six for 25 cents.

\section{Violets}

Violets, 10 cents each; three for 25 cents; $\$ 1.00$ per dozen.

Of all delightful perfumes, that of the Sweet Violet is the most delicate and pleasing. If grown in the house for winter flowers, they should be kept at a low temperature; they will not bloom freely where it is too warm. If left in the open ground during the winter, protect with a covering of leaves.

Princess of Wales - Broad Pansy-like flowers of a beautiful violet purple shade, with lighter center. A vigorous growing plant with clean, healthy foliage and stiff, long stems. One of the most beautiful and free-flowering violets.

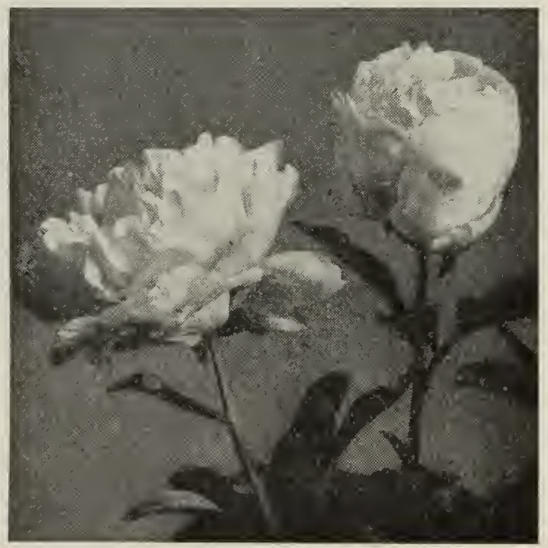

Maxima Festiva Peony

\section{Peonies}

That Herbaceous Peonies are as fine and effective in their way as Rhododendrons or Roses is now being generally recognized. They are hardier and more easily cultivated than either of their rivals, and are being used in the same way for bold display of color. Their flowers are very lasting; some of them are finely finished and exquisitely colored. Plant in deep, rich, well-prepared soil, covering the buds but an inch or two. Do not expect too much of them the first year. They are a little slow in establishing themselves.

Peonies are too large to be sent by mail. We can furnish red, white and pink, strong plants. 20 cents each; 6 for $\$ 1.00$. 
Delicatissima - This beautiful flower should be in every garden. Very large; delicate, clear pink, lighter in the center; very fragrant; free bloomer; exceptionally pretty in the bud; a quality flower in every sense. It is unexcelled as a cut flower. 35 cents each; $\$ 3.50$ per dozen.

Festiva Maxima-About the largest and undoubtedly the most popular Peony of them all. High built flowers borne on long, stiff stems; the purest white inner petals slightly tipped carmine. Early. 35 cents each; $\$ 3.50$ per dozen.

Edulis Superba-(Lemon)-Very large, bright rose flower; a beautiful early variety. 30 cents each.

Pottsii-Dark crimson; yellow stamens showing through the flower, early. 30 cents each.

Nigra-(Terry)-Full double flower; the darkest crimson of any; long, willowy stems; blooms late, 30 cents each.

Modest Guerin-Brilliant carmine-rose, with a high and stiff center full of rosy-pink petals. 35 cents each; $\$ 3.50$ per dozen.

Queen Victoria-The broad guard petals are a pretty bluish white; center slightly edged pink. Large. 30 cents.

\section{Golden Glow}

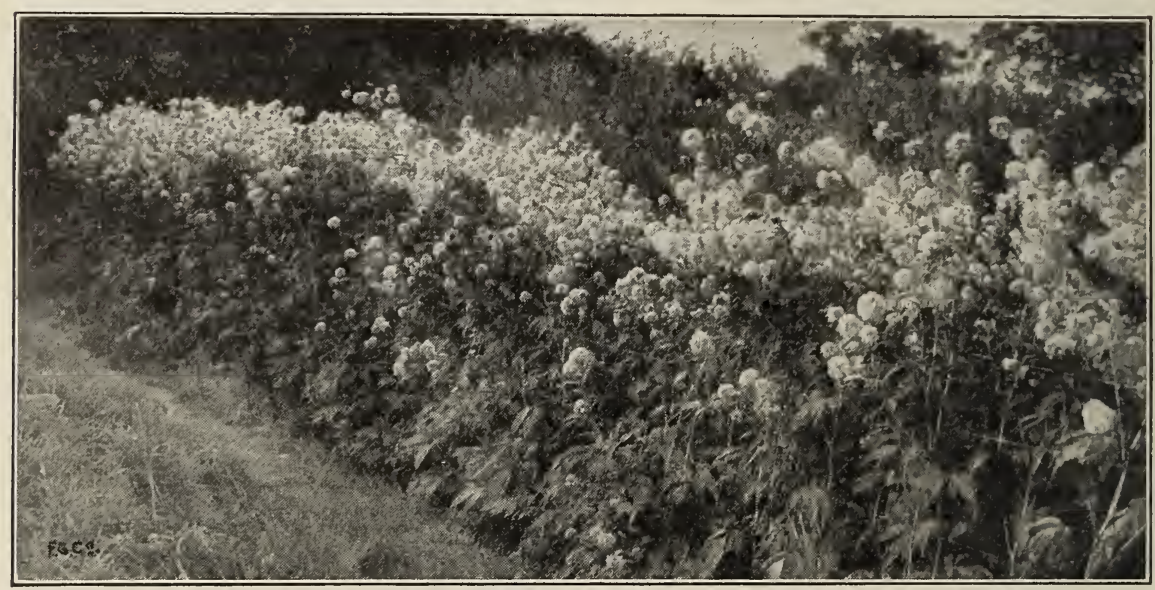

Golden Glow

Golden Glow-The most prolific and satisfactory of all yellow-flowering sorts. Grows 5 to 7 feet and blooms from early summer until frost. Flowers are produced on long stems in enormous quantities, and resemble golden-yellow Cactus Dahlias. 10 cents each; 75 cents per dozen.

\section{Feverfew}

A fine house plant with bright foliage and double pure white flowers. 10 cents each; three for 25 cents.

\section{Dicentra--Bleeding Heart}

D. Spectabilis-A hardy perennial with heart-shaped, rose-colored flowers in drooping spikes. One of the best border plants. Perfectly hardy and easily cultivated; 2 feet high. Flowers in April or May. 25 cents each.

\section{Bulbs for Fall}

Hyacinths-Red, white and blue. 10 cents each; three for 25 cents.

Crocuses-Assorted colors. 5 cents each; six for 25 cents.

Narcissus-Pure white. 5 cents each; six for 25 cents.

Tulips-Assorted colors, single and double. 5 cents each; 50 cents per dozen. 


\section{Phlox}

No class of hardy plants is more desirable than the Perennial Phloxes. They will thrive in any position and can be used to advantage in the hardy bor-

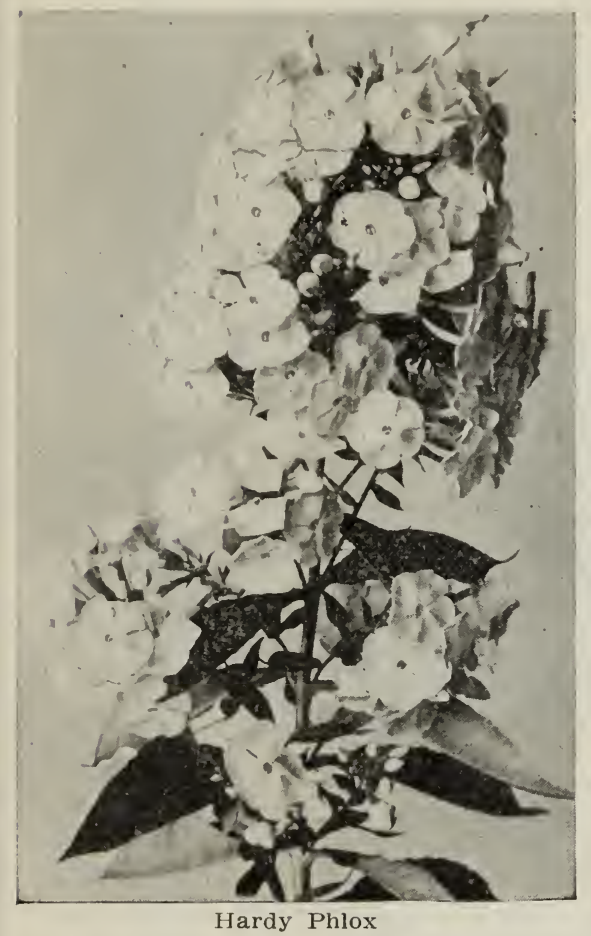

der, in large groups on the lawn, or planted in front of belts of shrubbery where, by judicious pinching back and removing faded flowers, a constant succession of bloom may be had until frost.

Mixed colors: Red, white, pink and lavender, $15 \mathrm{c}$ each; 8 for $\$ 1.00$.

\section{California Moss Pink}

A plant not well known, but we consider it among the very best for hanging baskets or planted in open ground. Postpaid, 10 cents each; $\$ 1.00$ per dozen.

\section{Assorted Plants}

We can furnish the following small plants postpaid at prices named below. Snapdragon-Red, white and pink, 10 cents each; $\$ 1.00$ per dozen.

Asters-Assorted colors; 5 cents each; 40 cents per dozen.

Sweet Alyssum -5 cents each; 40 cents per dozen.

Cosmos-Assorted colors; 5 cents each; 40 cents per dozen.

Marguerite Daisy-10 cents each; $\$ 1.00$ per dozen.

English Ivy-10 cents each; $\$ 1.00$ per dozen.

German Ivy-10 cents each; $\$ 1.00$ per dozen.

Pansies-Assorted colors; 5 cents each; 50 cents per dozen.

Verbenas-White, red, pink and blue; 5 cents each; 50 cents per dozen.

Wandering Jew-Red and green; 5 cents each; 40 cents per dozen.

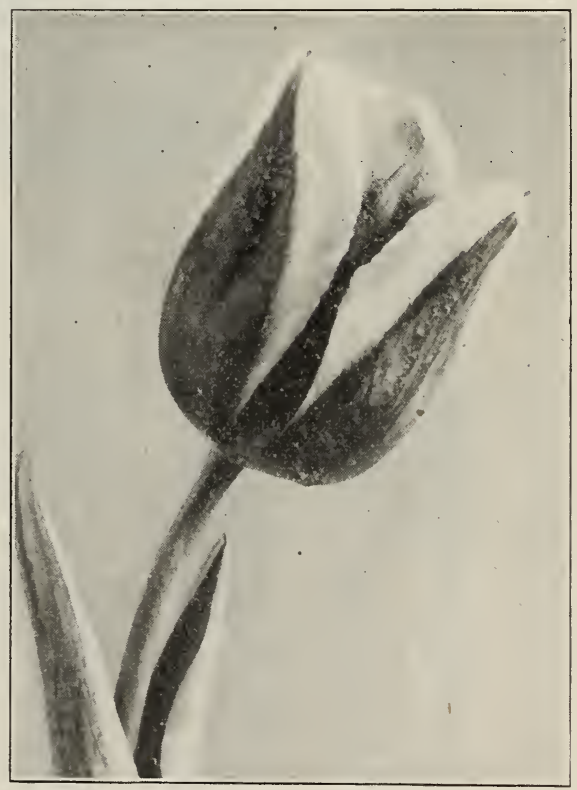

Tulip 


\section{Barred Plymouth Rocks}

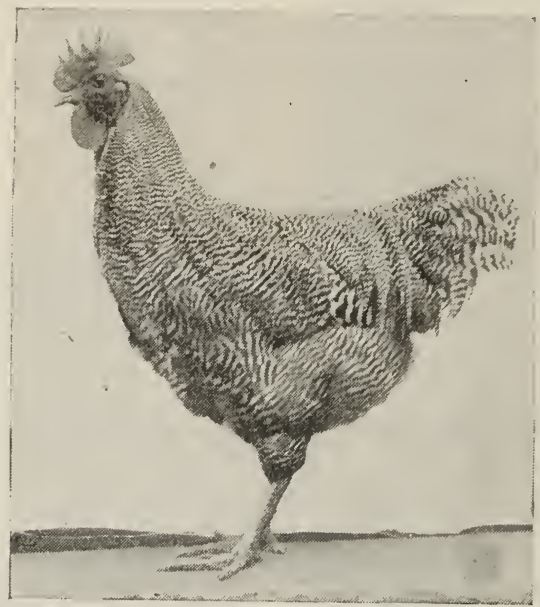

We have been breeding and showing Barred Plymouth Rocks for the last ten years, not so much for the money there is in it for us (they are very profitable) but because they are a popular variety, hard to breed to the standard of perfection, and there is always such hot competition in this variety at our large shows that the breeder who can win a few first or second premiums has won something he may well be proud of.

Prices-Eggs from pens mated to produce exhibition cockerels or pullets, $\$ 2.50$ per 15 eggs; eggs from birds that have farm range, $\$ 1.00$ per 15 eggs; $\$ 3.00$ per 50 eggs; $\$ 5.00$ per 100 eggs.

Cockerels-At $\$ 2.00$ each. If you want show birds, write us for prices. 
THE FAIRBUR Y NURSERIES, FAIRBURY, NEBRASKA

\begin{tabular}{|c|c|c|c|c|c|c|}
\hline 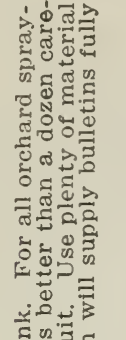 & $\begin{array}{l}\frac{5}{0} \\
\frac{2}{2} \\
\frac{\pi}{0} \\
\frac{0}{0} \\
\frac{0}{2} \\
\frac{0}{4} \\
\frac{5}{4} \\
\frac{4}{4}\end{array}$ & 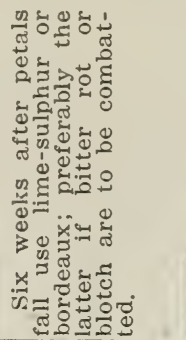 & & 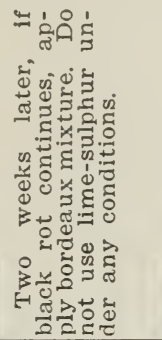 & & \\
\hline 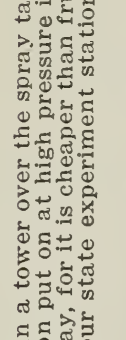 & 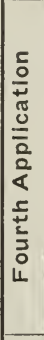 & 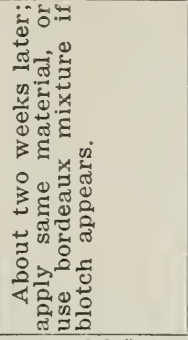 & & 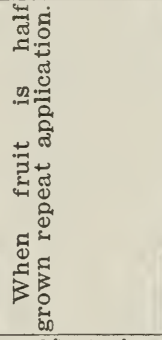 & 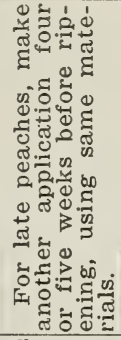 & \\
\hline 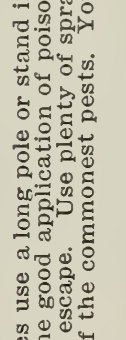 & 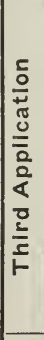 & 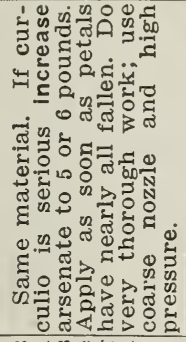 & 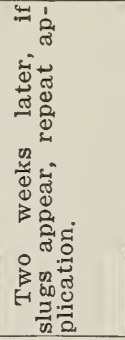 & 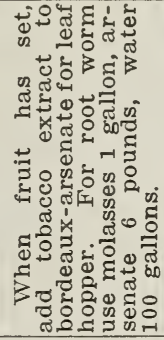 & 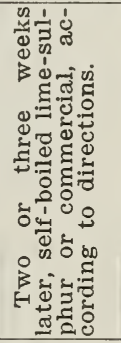 & 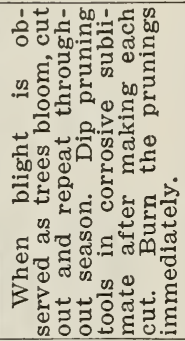 \\
\hline 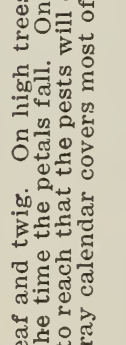 & 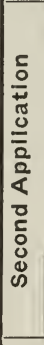 & 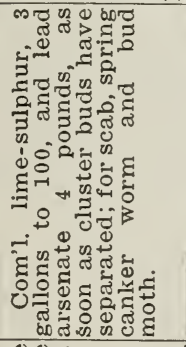 & 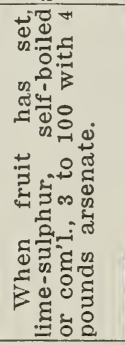 & 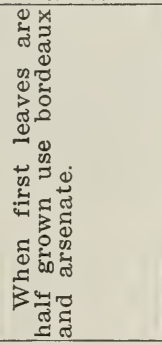 & 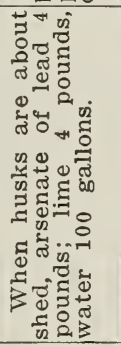 & 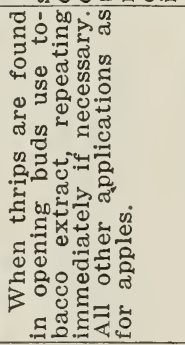 \\
\hline 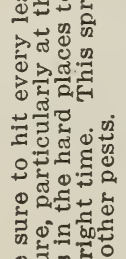 & $\begin{array}{l}\frac{5}{0} \\
\frac{0}{\pi} \\
0 \\
\frac{0}{0} \\
\frac{0}{2} \\
\frac{0}{\alpha} \\
\frac{0}{2} \\
\frac{2}{4}\end{array}$ & 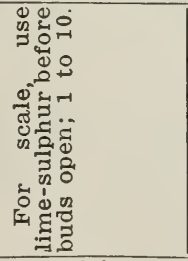 & 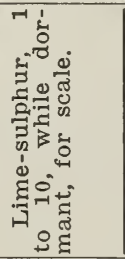 & 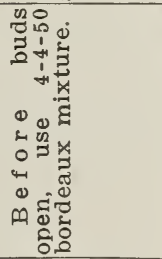 & 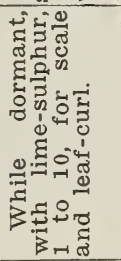 & 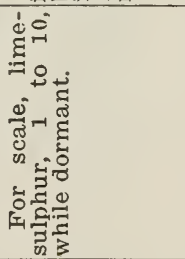 \\
\hline 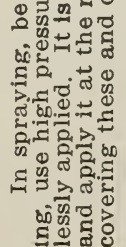 & $\frac{\frac{1}{3}}{\frac{2}{2}}$ & 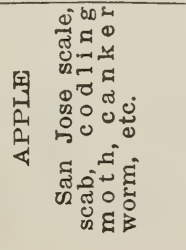 & 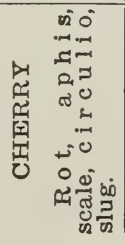 & 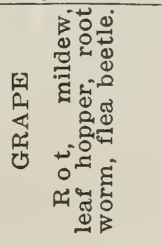 & 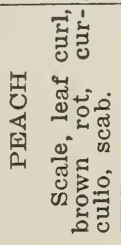 & 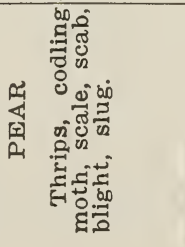 \\
\hline
\end{tabular}




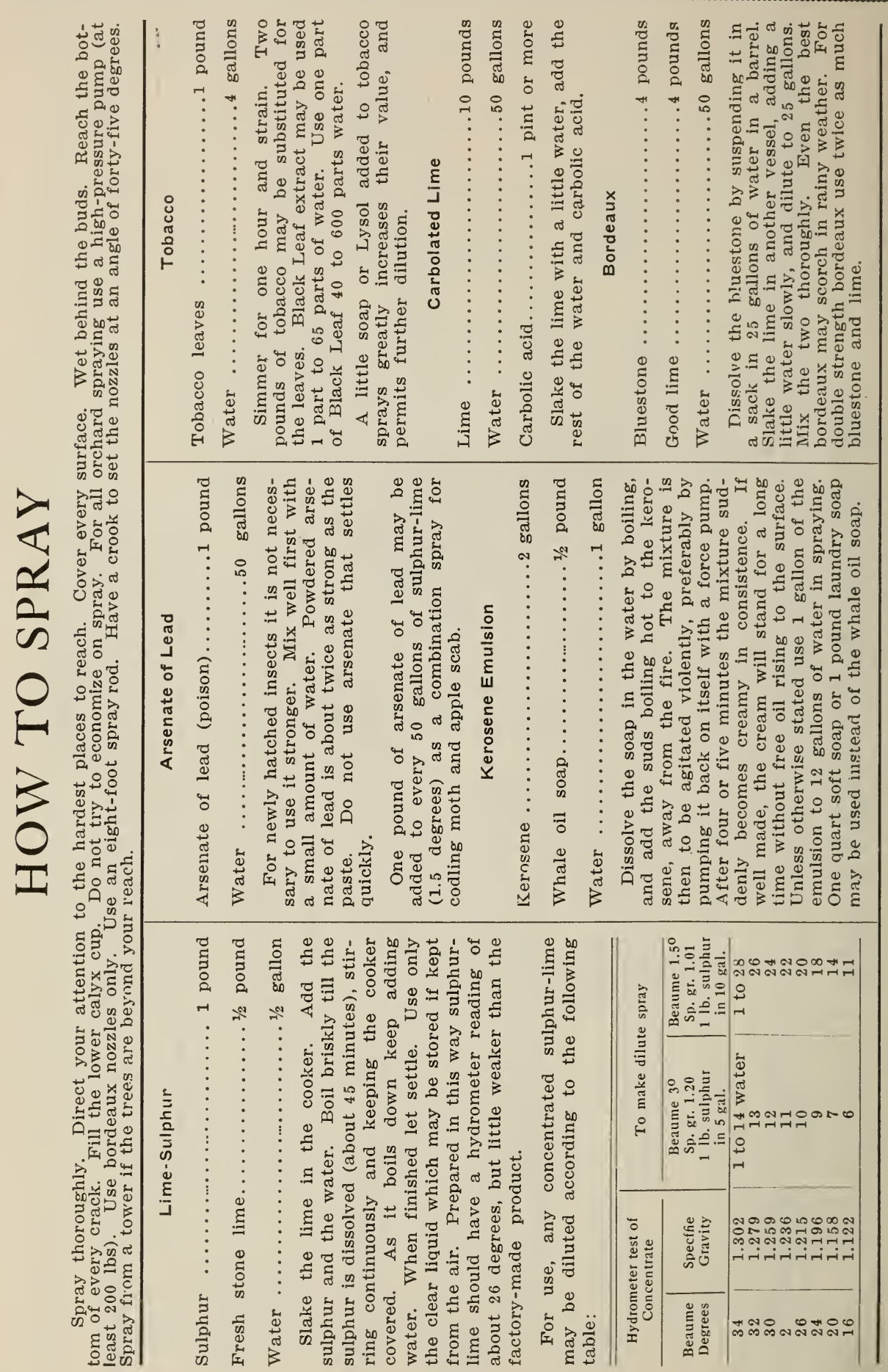




\section{SEED POTATOES}

We are now prepared to furnish our customers with first-class seed potatoes and would be pleased to receive a trial order from you.

Extra Early Ohio-(Red River Grown)-This is without doubt the most popular early potato in the country. We have more calls for it than any other early. Everyone knows what it is and knows that it can be relied upon for an early market variety in almost every locality. They are smooth, clean and free from prongs and scab. They grow stronger and more vigorous, maturing the crop in shorter time and yielding much more than home grown seed, so that there is the utmost satisfaction in planting them. Potato growers in the South will have their crop ready for the market from ten days to two weeks earlier if our Red River Valley Ohios are planted. This variety is sometimes sold under the name of Early Six Weeks Potato. It will pay to change your seed this year and plant a few acres of our selected stock of Ohios. Price, peck, 50 cents; bushel, $\$ 1.75$; three bushels, $\$ 5.00$.

Rural New Yorker-Is a large, white-skinned variety, oval in form, and rather flattish; flesh is white and close-grained, solid and of the very best quality; it cooks dry and floury; eyes are few and shallow. The tubers are large and the smoothest and cleanest of all potatoes grown. Although it is a large yielder, it grows but few and small vines. It is very hardy and will stand the heaviest manuring without getting rough or scabby. Price, peck, 40 cents; bushel, $\$ 1.50$; three bushels, $\$ 4.00$.

Early Irish Cobbler-In shape the Cobbler is round, with oval cross-section. Skin white, well netted. Flesh pure, pearly white. Eyes are very few and shallow. Its cooking qualities and flavor are first class. Tubers are of good size, no small ones, and very smooth and free from scab. It is one of the most reliable of the first early sorts. It ripens very evenly, every hill seeming to ripen at one time. Its strong growth, earliness, productiveness, fine eating quality, and handsome appearance will always cause a good demand for the Early Irish Cobbler. Price, peck, 50 cents; bushel, $\$ 1.75$; three bushels, $\$ 5$. We also have some small-sized seed potatoes of this variety at 25 cents per peck, 80 cents per bushel, three bushels for $\$ 2.25$.

Burbank-An old standard main crop variety which is very popular because of market demand and heavy yields. Satisfies both the grower and the consumer. Tubers are large, oblong and have fairly deep eyes. Color white, quality excellent, cooking very mealy and of attractive whiteness that pleases. It is the standard. arket potato in most of the potao-growing districts and contends with Rural New Yorker and Carman for first place. Our seed was grown in northern Wisconsin and is first class. Price, peck, 40 cents; bushel, $\$ 1.50$; three bushels, $\$ 4.00$.

\section{SEED SWEET POTATOES}

Yellow Jersey, 4 cents per pound by express; by mail, prepaid, 8 cents per pound. Do not order them shipped until you are ready to plant them.

\section{Customers pay the Express or Freight on Seed Potatoes}



THIRD ASSISTANT POSTMASTER GENERAL DIVISION OF MONEY ORDERS

The Postmaster will insert

\begin{tabular}{|l|l|}
\hline DOLLARS & CENTS \\
\hline
\end{tabular}

here

the office drawn on, when the office named by

Stamp of lssuing Office

the remitter in the body of this application is not a Money Order Office

Spaces above this line are for Postmaster's record, to be filled in by him

\section{Application for Domestic Money Order}

Spaces below to be filled in by purchaser, or if necessary, by another person for him

Amount

Dollars Cents
Pay to
Order of
C. M. HURLBURT, Fairbury, Nebraska

Sent by

(Name of Sender)

Address )

of $\}_{\text {ender }}$ No.

Street

PURCHASER MUST SEND ORDER AND COUPON TO PAYEE

\section{FROM}

\section{FAIRBURY NURSERIES,}

C. M. HURLBURT, Manager,

\section{Fairbury,}






\section{State Entomologist's Certificate of Nursery Inspection}

THIS IS TO CERTIFY that on the 13th day of August, 1913, the growing stock and premises of the Fairbury Nursery, C. M. Hurlburt. Prop., of Fairbury, Nebraska, was inspected, and no San Jose scale was found nor any indication that it had ever been present in the nursery or its vicinity. The stock is apparently in a healthy condition and free from other dangerous insect pests and fungous diseases.

This certificate is good until July 1, 1914.

LAWRENCE BRUNER, State Entomologist, By John T. Zimmer, Deputy.

Cut This Out and Return With Your Order

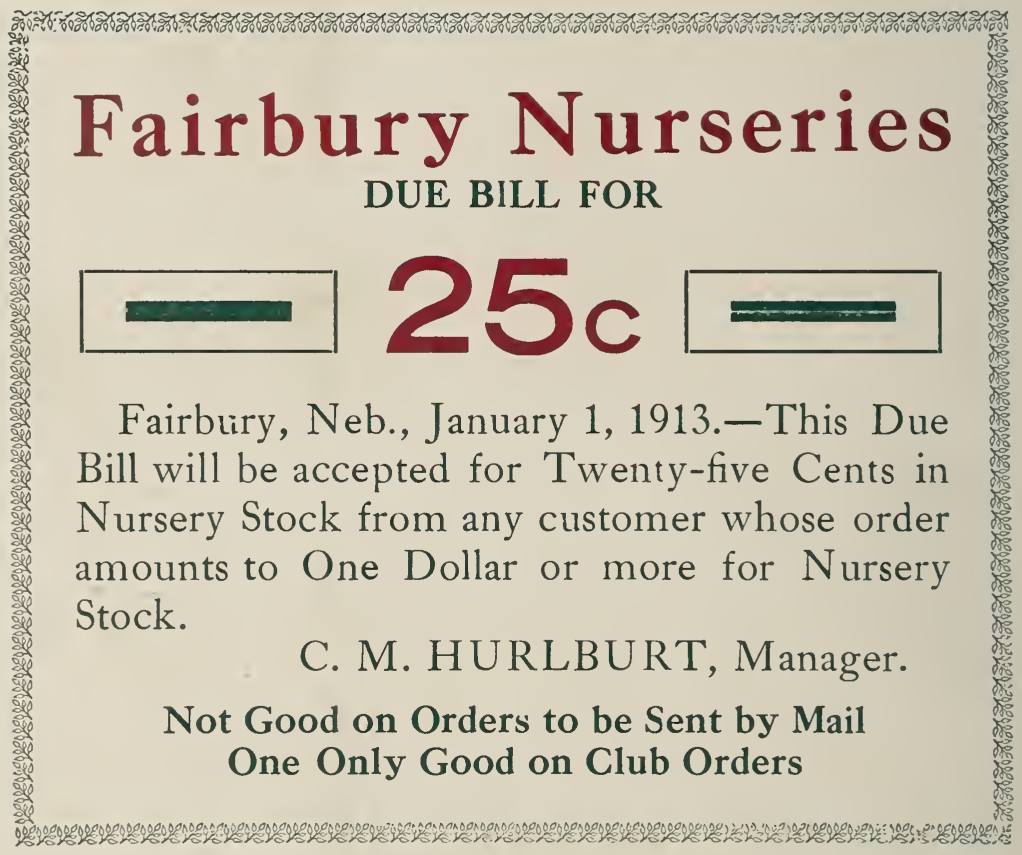

Address C. M. HURLBURT, Manager, Fairbury, Neb. 